OPEN ACCESS

Edited by:

Diana Dudziak,

Universitätsklinikum Erlangen,

Germany

Reviewed by:

Susan Kovats,

Oklahoma Medical Research

Foundation, United States

Jennifer Johanna Lühr,

University Hospital Erlangen,

Germany

*Correspondence:

Stefanie Scheu

stefanie.scheu@uni-duesseldorf.de

Specialty section:

This article was submitted to Antigen Presenting Cell Biology, a section of the journal

Frontiers in Immunology

Received: 31 August 2018 Accepted: 25 March 2019

Published: 12 April 2019

Citation:

Ali S, Mann-Nüttel R, Schulze A, Richter L, Alferink J and Scheu S

(2019) Sources of Type I Interferons in Infectious Immunity: Plasmacytoid

Dendritic Cells Not Always in the

Driver's Seat. Front. Immunol. 10:778. doi: 10.3389/fimmu.2019.00778

\section{Sources of Type I Interferons in Infectious Immunity: Plasmacytoid Dendritic Cells Not Always in the Driver's Seat}

\author{
Shafaqat Ali ${ }^{1,2}$, Ritu Mann-Nüttel ${ }^{1}$, Anja Schulze ${ }^{1}$, Lisa Richter ${ }^{1}$, Judith Alferink ${ }^{2,3}$ and \\ Stefanie Scheu ${ }^{1 *}$ \\ ${ }^{1}$ Institute of Medical Microbiology and Hospital Hygiene, University of Düsseldorf, Düsseldorf, Germany, ${ }^{2}$ Cluster of \\ Excellence EXC 1003, Cells in Motion, Münster, Germany, ${ }^{3}$ Department of Psychiatry, University of Münster, Münster, \\ Germany
}

Type I Interferons (IFNs) are hallmark cytokines produced in immune responses to all classes of pathogens. Type I IFNs can influence dendritic cell (DC) activation, maturation, migration, and survival, but also directly enhance natural killer (NK) and T/B cell activity, thus orchestrating various innate and adaptive immune effector functions. Therefore, type I IFNs have long been considered essential in the host defense against virus infections. More recently, it has become clear that depending on the type of virus and the course of infection, production of type I IFN can also lead to immunopathology or immunosuppression. Similarly, in bacterial infections type I IFN production is often associated with detrimental effects for the host. Although most cells in the body are thought to be able to produce type I IFN, plasmacytoid DCs (pDCs) have been termed the natural "IFN producing cells" due to their unique molecular adaptations to nucleic acid sensing and ability to produce high amounts of type I IFN. Findings from mouse reporter strains and depletion experiments in in vivo infection models have brought new insights and established that the role of pDCs in type I IFN production in vivo is less important than assumed. Production of type I IFN, especially the early synthesized IFN $\beta$, is rather realized by a variety of cell types and cannot be mainly attributed to pDCs. Indeed, the cell populations responsible for type I IFN production vary with the type of pathogen, its tissue tropism, and the route of infection. In this review, we summarize recent findings from in vivo models on the cellular source of type I IFN in different infectious settings, ranging from virus, bacteria, and fungi to eukaryotic parasites. The implications from these findings for the development of new vaccination and therapeutic designs targeting the respectively defined cell types are discussed.

Keywords: type I interferon, plasmacytoid dendritic cells, interferon producing cells, infection, pathogen, virus, immunopathology, immune activation

\section{INTRODUCTION}

The cytokine family of type I IFNs fulfills key functions in anti-viral immunity but is also produced in the immune responses to other classes of pathogens covering viruses, bacteria, parasites, and fungi (1). Additionally, these cytokines are functionally involved in the pathogenesis of inflammatory autoimmune diseases (2). 
Together with IFN $\beta$, type I IFNs comprise multiple IFN $\alpha$ subtypes (11 in mice and 13 in humans), IFN $\varepsilon$, IFNא, and IFN $\omega$ in most mammals. In addition, IFN $\delta$, IFNל (limitin), and IFN $\tau$ have been detected exclusively in pigs, mice, and ruminants, respectively (3-6). Type I IFNs are encoded by intronless genes clustered in mice on chromosome 4 and in humans on chromosome 9 (3-6). Induction of type I IFN expression is facilitated after activation of a diverse set of pathogen sensing pattern recognition receptor (PRR) pathways by binding of IFN regulatory factors (IRFs) and NF- $\kappa B$ to acute response elements in the promoters of type I IFN gene loci (7). All type I IFNs bind to a common heterodimeric IFN $\alpha$ receptor (IFNAR), which is composed of the IFNAR1 and IFNAR2 subunits and is expressed by virtually all nucleated cells of the body. Following IFNAR engagement by its ligands, canonical type I IFN signaling activates the Janus kinase (JAK)signal transducer and activator of transcription (STAT) pathway, leading to transcription of IFN-stimulated genes (ISGs) (5, 8). ISG-encoded proteins mediate induction of cell-intrinsic antimicrobial states in infected and neighboring cells that limit the spread of infectious agents, particularly viral pathogens. Additionally, ISGs influence innate and adaptive immune responses by promoting antigen presentation and NK cell functions, modulating inflammatory cytokine production, and activating high-affinity antigen-specific $\mathrm{T}$ and $\mathrm{B}$ cell responses and immunological memory (9). Type I IFN production, however, can also have deleterious roles in chronic viral and bacterial infections, and can lead to immunopathologies such as inflammatory disorders and autoimmunity $(1,2,10,11)$.

IFN $\beta$ was originally defined as the antiviral factor produced by fibroblasts after viral infections (12) and has been thought to be produced by virtually all cells of the body. Later pDCs specialized in the rapid secretion of high amounts of type I IFN have been termed the natural "IFN producing cells" (IPCs). Recent findings, however, indicate that production of type I IFN, especially the early synthesized IFN $\beta$, in anti-infectious immune responses can occur independently of pDCs and that the cell type responsible for type I IFN production rather depends on the specific infectious setting. In this review we summarize the recent findings on the identity and function of type I IFN producing cells in infection by focusing on insights gained from in vivo mouse models covering type I IFN reporter mice and models of cell type specific ablation.

\section{Pathways of Type I IFN Activation in Different Cell Types}

To devise novel anti-infectious treatment regimens targeting a specific cellular subtype, it is crucial to know the identity of the cells responsible for the production of type I IFN in the course of an infection. Early on, pDCs were considered primary producers of IFN $\alpha$ during virus infections $(13,14)$. For human pDCs it has been reported that IFN $\alpha / \beta$ transcripts account for an astounding $50 \%$ of all mRNAs in the cell after viral activation (15). More than 40 years ago, pDCs were first described in humans as natural IPCs that activate NK cells upon exposure to viruses $(16,17)$. The murine equivalent was described in 2001 as type
I IFN producing cells with plasmacytoid morphology (18-20). These cells detect RNA and DNA viruses through two endosomal sensors, TLR7 and TLR9, respectively, which induce secretion of type I IFN through the MyD88-IRF7 signaling pathway (2124). Specifically, TLR7/9-ligand interactions in early endosomes result in type I IFN production while ligand recognition in late endosomes or lysosomes rather leads to inflammatory cytokine production and pDC maturation $(25,26)$. At least in the mouse, TLR7 and 9 are also expressed by monocytes, conventional DCs (cDCs), and B cells $(27,28)$. Therefore, the contribution of those cell types to type I IFN production triggered via the TLR7/9MyD88-IRF7 pathway has to be considered. B cells, for instance, have recently been shown to produce type I IFN in vivo after optimized stimulation conditions using the TLR9 ligand CpGA (29). A specific feature of pDCs is that they can produce type I IFN independently of IFNAR mediated feedback signaling (30). However, they do respond to type I IFN by generating an autocrine circuit through IFNAR, which augments type I IFN secretion and induces their activation and migration $(31,32)$.

In humans, pDCs, monocytes, and other myeloid cells also produce type I IFN after stimulation of the TLR8-MyD88-IRF7 pathway by viral single-stranded RNA (ssRNA) $(33,34)$. The mouse TLR8 was initially considered non-functional $(33,34)$. More recently it has been shown that mouse TLR8 can be stimulated by a combination of oligodeoxynucleotides (ODNs) and human TLR8 ligands. Further, mouse pDCs produce type I IFN after stimulation with vaccinia virus (VV) in a TLR8 dependent way $(35,36)$. Two additional TLRs, TLR3 and 4, are able to induce type I IFN expression independently of the MyD88 pathway via recruiting the TIR domain-containing adaptor protein inducing interferon beta (TRIF; also known as TIR domain-containing adapter molecule 1, TICAM-1). This activates the transcription factor IRF3 thus initiating type I IFN, in particular IFN $\beta$ expression $(37,38)$. TLR3 is absent in mouse pDCs but highly expressed in endosomes of murine $\mathrm{CD} 8 \alpha^{+}$ and $\mathrm{CD}_{103}{ }^{+}$and human $\mathrm{CD} 141^{+} \mathrm{cDCs}$ of the DC1 subtype that are efficient in cross-presenting $(39,40)$. It recognizes double-stranded RNA (dsRNA) as viral replication intermediates as well as ssRNA containing stem loops (41). In addition to DCs, TLR3 activation can lead to type I IFN expression in macrophages, fibroblasts, and epithelial cells (42). While TLR3 exclusively signals via the TRIF pathway, TLR4 utilizes MyD88 as well as TRIF signaling routes after recognizing its cognate ligand bacterial lipopolysaccharide (LPS). Analogous to TLR3 activation, LPS binding to TLR4 induces type I IFN expression via TRIF-IRF3 (43). The majority of hematopoietic cells of the myeloid and lymphoid lineage, with the exception of human pDCs, and few other cell types such as pancreatic $\beta$-cells express TLR4 (44).

In contrast to $\mathrm{pDCs}, \mathrm{cDCs}$, and macrophages mainly produce type I IFN in response to virus challenge by utilizing retinoic acidinducible gene I (RIG-I)-like helicases (RLHs) (43, 45-47). RLHs, including RIG-I and melanoma differentiation-associated gene 5 (MDA5), are cytoplasmic dsRNA receptors that transmit their signal through the mitochondrial antiviral-signaling protein, virus-induced signaling adapter (MAVS, aka IFNb promoter stimulator (IPS)-1 or Cardif). This activates IRF3 and IRF7 
to induce the transcription of type I IFN and other antiviral genes (48-50).

Finally, soluble sensors in the cytoplasm detect dsDNA in a sequence-independent manner, exhibit a broad expression spectrum including pDCs, cDCs, macrophages, and mouse embryonic fibroblasts (MEFs), and activate signaling pathways leading to type I IFN expression $(47,51)$. These sensors include the cyclic GMP-AMP synthase (cGAS)/STING pathway, the RNA polymerase III/RIG-I/MAVS pathway, DNA-dependent activator of IRFs (DAI), IFN $\gamma$-inducible protein 16 (IFI16), and the DDX family $(47,51-58)$.

\section{Mouse Models and in vivo Experimental Strategies for the Definition of the Cellular Source of Type I IFNs in Infection}

Several models of cytokine reporter mice have been developed for the detection of type I IFN production in vivo, as intracellular staining is not sensitive in most cases (Table $\mathbf{1}$ and Figure 1). Earlier published IFN $\beta$ knock-out mouse lines already contained reporter elements to detect Ifnb promoter-driven gene transcription. For example, coding sequences for the mouse immunoglobulin $\lambda 2$ chain, a green fluorescent protein (GFP), or the human CD2 had been inserted immediately downstream of the If $n b$ promoter to visualize IFN $\beta$ expression on a cellular level (73-75). However, the reporter features in these mouse strains have not been used in vivo so far.

More recently, a mouse line expressing GFP under the control of the Ifna6 promoter (Ifna $6^{\mathrm{gfp} /+}$ ) recapitulates the expression of various IFN $\alpha$ genes and has been employed to define the cellular source of IFN $\alpha$ in virus infection models $(32,46,76)$. Also, for IFN $\beta$ a fluorescence reporter-knock-in mouse model (IFN $\beta^{\text {mob/mob}}$ ) has been generated. Here, yellow fluorescent protein (YFP) is expressed from a bicistronic mRNA linked by an internal ribosomal entry site (IRES) to the endogenous IFN $\beta$ mRNA (59). Ifna6 ${ }^{\mathrm{gfp} /+}$ as well as IFN $\beta^{\mathrm{mob} / \mathrm{mob}}$ reporter mice have each been shown to report for the majority of type I IFNs. However, in vitro analyses on BM-derived DCs from the double reporter mouse line generated by intercrossing the Ifna $6^{\mathrm{gfp} /+}$ and IFN $\beta^{\text {mob/mob }}$ reporter strains revealed that specific type I IFN subtypes can be produced by distinct cell subpopulations (77).

In an alternative reporter mouse system, a firefly luciferase reporter gene has been placed under the control of the Ifn $b$ promoter (IFN- $\beta^{+/ \Delta \beta}$-luc $)$. Rather than IFN $\beta$ expression on a single cell level, this model detects in vivo kinetics of IFN $\beta$ expression in the mouse paralleling the spread of pathogens through the organism under infectious conditions (60). Additionally, in this mouse line the IFN $\beta$ coding sequence is flanked by $\operatorname{lox} P$ sites (IFN- $\beta^{\text {flox } \beta-\text { luc } / \text { flox } \beta-l u c}$ ) providing the possibility to characterize the impact of IFN $\beta$ production by a given cell type on the pathophysiology of various infections via tissue- or cell-specific Cre-mediated deletion of IFN $\beta$ (60).

\section{Methods and Models for Assessing the Impact of Type I IFN Producing Cell Populations in vivo}

Several experimental strategies have been developed to determine the in vivo contribution of a specific cell type to the type I
IFN response during infections (78). Initially, antibody mediated depletion has been utilized frequently to ablate pDCs and monocytes (79). Antibodies against Ly6G/C (also known as Gr1) and CD317 (also known as BST-2) have been used to deplete pDCs in vivo and in vitro $(18,79-87)$. However, these antibodies generally target multiple cell types in addition to pDCs: The antibody RB6-8C5 directed against Ly6G/C reacts strongly with neutrophil-specific Ly6G antigen, but cross-reacts also with the Ly6C Ag (88) expressed on pDCs as well as on monocytes/macrophages, activated T cells, NK cells, plasma cells, and endothelial cells (89-92). Likewise, CD317 is recognized by the three different antibody clones 120G8.04, JF05-1C2.4.1 (also known as PDCA-1), and eBio927, and is expressed in naïve mice by pDCs, but also plasma cells. Following stimulation with type I IFNs and IFN $\gamma$ CD317 is upregulated, additionally, on several other myeloid and lymphoid cells $(79,93)$. Finally, in vivo treatment with clodronate-containing liposomes depletes phagocytes in mice, but also disturbs the microarchitecture of secondary lymphoid organs $(94,95)$.

In the past years, several genetically modified mouse lines with a constitutive or inducible lack of specific cell types attributed to produce type I IFN have become available (Table $\mathbf{1}$ and Figure 1) (78). For pDCs, already several mouse models exist for constitutive or inducible ablation. Mice carrying a hypomorphic mutation at the Ikaros locus express low levels of the transcription factor Ikaros $\left(\mathrm{Ik}^{\mathrm{L} / \mathrm{L}}\right)$ and therefore lack peripheral pDCs, but no other DC subsets (61). When using this line as a "pDC-less" model, one has to take into account that other hematopoietic lineages including $\mathrm{T}$ and $\mathrm{B}$ cells and neutrophils are also affected by the $\mathrm{Ik}^{\mathrm{L} / \mathrm{L}}$ mutation, and that $\mathrm{Ik}^{\mathrm{L} / \mathrm{L}}$ mice start to develop thymic lymphomas by 10 weeks of age $(62,96,97)$. Constitutive deletion of E2-2, the basic helix-loop-helix transcription factor, also known as TCF4, that controls development and maintenance of pDCs, results in perinatal lethality in mice (98). To overcome this lethality and to specifically ablate the pDC lineage, mice harboring a constitutively deleted and a floxed $T f c 4$ allele ( $\mathrm{Tcf} 4^{\text {flox } /-}$ ) have been crossed to Itgax-Cre (CD11c-Cre) or Rosa26-CreER mice in which Cre is expressed in DCs or can be induced ubiquitously after tamoxifen administration, respectively $(63,64$, 99, 100). Another strategy uses Diphtheria toxin receptor (DTR)mediated conditional and targeted cell depletion. CLEC4ADTR-tg mice express DTR under the human pDC specific promotor of the C-type lectin domain family 4 member A (CLEC4A; also known as blood dendritic cell antigen 2, BDCA2). Administration of diphtheria toxin (DT) in these CLEC4ADTR-tg mice results in transient but specific depletion of $\mathrm{pDCs}$ (65). In an alternative approach, a cDNA encoding the human DTR fused to the enhanced green fluorescent protein (EGFP) and preceded by an IRES was inserted into the $3^{\prime}$ untranslated region of the Siglech gene. This Siglech ${ }^{\mathrm{dtr} / \mathrm{dtr}}$ mouse model allows specific elimination of $\mathrm{pDCs}$ in vivo via injection of DT (66). An analogous mouse line termed SiglecH-DTR-tg was generated using bacterial artificial chromosome (BAC) transgenic technology (67). SiglecH represents a sialic acid-binding Ig-like lectin that exerts immunomodulatory roles in antiviral immune responses. In SiglecH $\mathrm{H}^{\mathrm{eGFP} /+}$ mice, heterozygous for the reporter gene, it was shown that in addition to $\mathrm{pDCs}$, SiglecH was 
TABLE 1 | Genetically modified mouse models to visualize or define the function of type I IFN producing cells.

\begin{tabular}{|c|c|c|c|}
\hline Function & Name(s) & Genetic modification & References \\
\hline IFNa6-GFP reporter mouse & Ifna6gfp/+ & $\begin{array}{l}\text { Knock-in of a GFP reporter gene into the Ifna } 6 \text { locus behind the Ifna6 } \\
\text { promoter; endogenous IFN } \alpha 6 \text { expression retained in homozygous } \\
\text { reporter mouse }\end{array}$ & $(46)$ \\
\hline IFN $\beta$-YFP reporter mouse & $\begin{array}{l}\text { IFN } \beta^{\text {mob/mob }}(\mathrm{B} 6.129- \\
\text { Ifnb1tm1Lky/J) }\end{array}$ & $\begin{array}{l}\text { Knock-in of an IRES-driven YFP reporter cassette behind the Stop } \\
\text { codon of the Ifnb1 gene; endogenous IFN } \beta \text { expression retained in } \\
\text { homozygous reporter mouse }\end{array}$ & (59) \\
\hline $\begin{array}{l}\text { IFN } \beta \text {-luciferase reporter and conditional IFN } \beta \\
\text { knock-out }\end{array}$ & 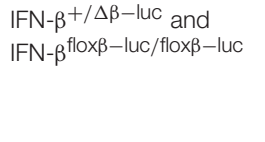 & $\begin{array}{l}\text { Knock-in of firefly luciferase reporter gene into the Ifnb1 locus behind } \\
\text { the Ifnb1 promoter; endogenous IFN } \beta \text { expression retained in } \\
\text { homozygous reporter mouse; IFN } \beta \text { coding sequence has been flanked } \\
\text { by loxP sites. }\end{array}$ & $(60)$ \\
\hline $\begin{array}{l}\text { Constitutive pDC ablation (caveat: T and B cells, } \\
\text { and neutrophils affected) }\end{array}$ & $\mathrm{Ik}^{\mathrm{L} / \mathrm{L}}$ & $\begin{array}{l}\text { Knock-in of the } \beta \text { gal coding sequence in-frame into exon- } 2 \text { of the } \\
\text { Ikaros gene resulting in a hypomorphic mutation }\end{array}$ & $(61,62)$ \\
\hline Constitutive pDC ablation & Tcf4 $4^{f l o x} /-$ Itgax-Cre $^{+}$ & Floxed Tcf4 gene crossed to DC specific Itgax-CRE mice & $(63,64)$ \\
\hline Inducible pDC ablation & Tcf4 ${ }^{f l o x} /-R 26$-CreER ${ }^{+}$ & Floxed Tcf4 gene crossed to tamoxifen-inducible $R 26$-CreER mice & $(64)$ \\
\hline $\begin{array}{l}\text { Inducible transient pDC depletion after diphtheria } \\
\text { toxin (DT) administration }\end{array}$ & $\begin{array}{l}\text { CLEC4A-DTR-tg } \\
\text { (BDCA2-DTR tg) }\end{array}$ & $\begin{array}{l}\text { Transgene containing a } 5 \mathrm{~kb} \text { fragment upstream of the ATG of the } \\
\text { human CLEC } 4 A \text { (BDCA-2) gene followed by the diphtheria toxin } \\
\text { receptor (DTR) CDNA }\end{array}$ & (65) \\
\hline $\begin{array}{l}\text { Inducible transient pDC depletion after DT } \\
\text { administration }\end{array}$ & Siglech ${ }^{d t r / d t r}$ & $\begin{array}{l}\text { Knock-in of an IRES-driven cDNA encoding the human DTR fused to } \\
\text { the enhanced green fluorescent protein (EGFP) into the 3' untranslated } \\
\text { region of the Siglech gene }\end{array}$ & $(66)$ \\
\hline $\begin{array}{l}\text { Inducible transient pDC depletion after DT } \\
\text { administration (caveat: MZM and pre-pDC affected) }\end{array}$ & SiglecH-DTR-tg & $\begin{array}{l}\text { BAC transgene, modified BAC encoding the complete Siglech gene } \\
\text { locus (RPA24-163A12), bicistronic cassette containing cDNAs for } \\
\text { human DTR and EGFP inserted into Siglech exon I, after the second } \\
\text { triplet of the open reading frame }\end{array}$ & $(67)$ \\
\hline $\begin{array}{l}\text { pDC-specific Cre expression (caveat: Cre mediated } \\
\text { recombination detected in a minor fraction of } \\
\text { SiglecH }{ }^{-} \text {B-, T-, NK-, and NK-T cells and splenic } \\
\text { CDC and CD11 int BM cells) }\end{array}$ & pDCre & $\begin{array}{l}\text { BAC transgene, modified BAC encoding the complete Siglech gene } \\
\text { locus (RP24-396N13), bicistronic cassette containing cDNAs for Cre } \\
\text { and mCherry inserted into Siglech exon I, after the ATG }\end{array}$ & (68) \\
\hline $\begin{array}{l}\text { Constitutive restriction of type I IFN production to } \\
\text { pDCs and tamoxifen inducible pDC specific Cre } \\
\text { expression }\end{array}$ & $\begin{array}{l}\mathrm{pDC}: \mathrm{IRF}^{+} \\
(\text {Siglech } \\
\left.\operatorname{lnf7} 7^{-/-}\right)\end{array}$ & $\begin{array}{l}\text { Knock-in of bicistronic cassette containing the irf7 gene locus } \\
\text { stretching (protein coding exons) and the cDNA for Cre fused to the } \\
\text { mutated ligand binding domain of the human estrogen receptor (ERT2), } \\
\text { backcrossed Irf3 }-/-; \text { Irf } 7^{-/-} \text {double knockout mice }\end{array}$ & (69) \\
\hline $\begin{array}{l}\text { Inducible transient cDC depletion after DT } \\
\text { administration }\end{array}$ & CD11c-DTR-tg & $\begin{array}{l}\text { Transgene containing the murine CD11c promoter followed by a cDNA } \\
\text { coding for a DTR-EGFP fusion protein }\end{array}$ & $(70)$ \\
\hline $\begin{array}{l}\text { Inducible transient monocyte depletion after DT } \\
\text { administration }\end{array}$ & CD11b-DTR-tg & $\begin{array}{l}\text { Transgene containing the human CD11b promoter followed by a cDNA } \\
\text { coding for a DTR-EGFP fusion protein }\end{array}$ & $(71)$ \\
\hline $\begin{array}{l}\text { Inducible transient monocyte depletion of marginal } \\
\text { metallophilic macrophages in the spleen and } \\
\text { subcapsular sinus macrophages in the lymph nodes } \\
\text { after DT administration }\end{array}$ & CD169-DTR-tg & $\begin{array}{l}\text { Knock-in of the cDNA for the human DTR into the endogenous gene } \\
\text { locus, behind the promoter for CD169. }\end{array}$ & $(72)$ \\
\hline
\end{tabular}

expressed in specialized macrophage subsets, such as marginal zone macrophages (MZM), lymph node medullary macrophages, and microglia. SiglecH was also found in immediate precursors of pDCs (pre-pDCs) in the BM, which have the plasticity to differentiate into pDCs and cDCs $(67,101)$. Despite of SiglecH expression on above described other cell types Loschko et al. showed pDC specific antigen delivery in mice by using SiglecH as a target structure (102) suggesting the usability of SiglecH as a lead molecule for the generation of $\mathrm{pDC}$ specific transgenic animals. A side by side comparison showed a higher susceptibility to Listeria monocytogenes infection in DT-treated SiglecH-DTRtg vs. CLEC4A-DTR-tg mice. This finding was attributed to the additional lack of MZM in SiglecH-DTR-tg mice after DT treatment which was not observed in CLEC4A-DTR-tg mice (67).

With the aim to specifically express the Cre recombinase in pDCs a BAC-tg "pDCre" mouse line was generated which expresses Cre under the control of the Siglech promoter (68). By crossing these mice with a reporter mouse line that indicates Cre activity via red fluorescent protein (RFP) expression the authors found $\sim 30 \%$ of SiglecH ${ }^{+}$pDCs terminally labeled with RFP. Additionally, RFP expression was observed in a minor fraction of SiglecH $\mathrm{H}^{-}$B-, T-, NK-, and NK-T cells and splenic cDCs and CD11cint $\mathrm{BM}$ cells suggesting that a small fraction of early lymphoid progenitors actively transcribes the SiglecH locus. Thus, the broader expression pattern of SiglecH should be considered when using SiglecH-DTR-tg mice to evaluate pDC functions in vivo.

Recently, a novel mouse model has been described in which type I IFN production is restricted to pDCs. In this knockin model Irf7 expression is driven by the Siglech promoter $\left(\right.$ Siglech $\left.^{\mathrm{Irf} 7 /+}\right)$. The Siglech ${ }^{\mathrm{Irf} 7 /+}$ mice were then backcrossed onto Irf $3^{-/-} / \mathrm{Irf}^{-/-}$double knock-out mice which are deficient 
A Reporter mouse models
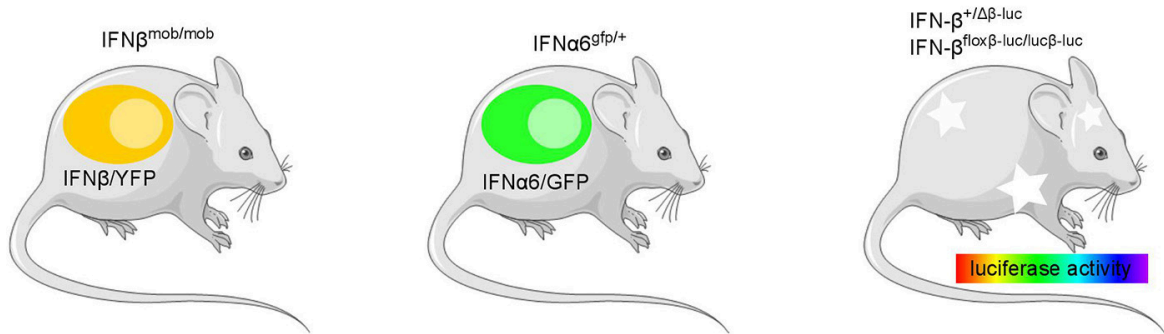

B Inducible transient DTR-mediated cell depletion
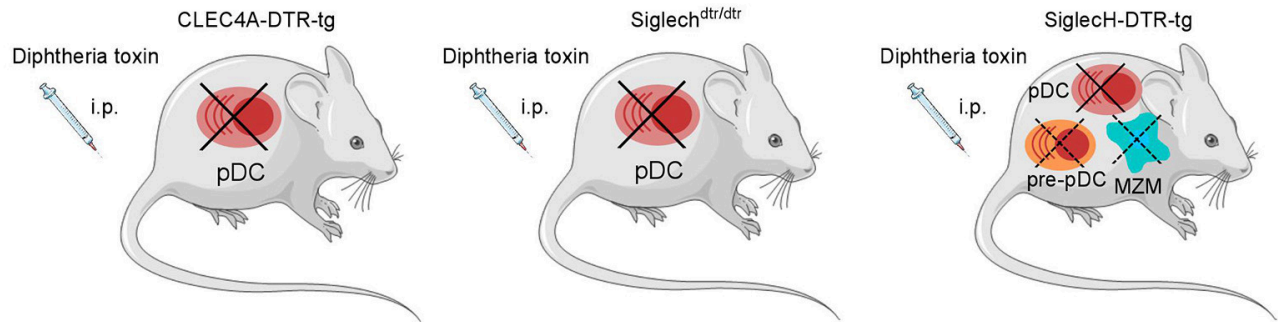

CD11b-DTR-tg

CD169-DTR-tg
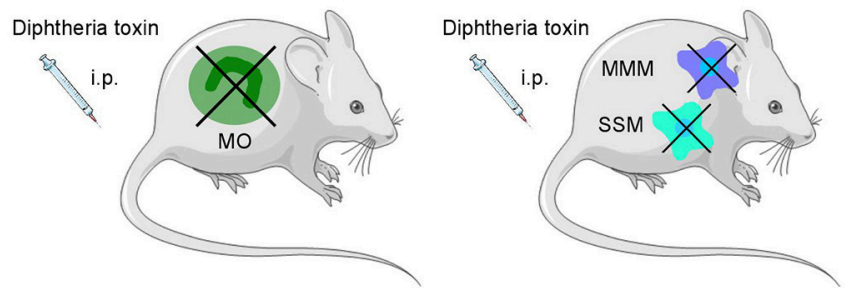

CD11c-DTR-tg

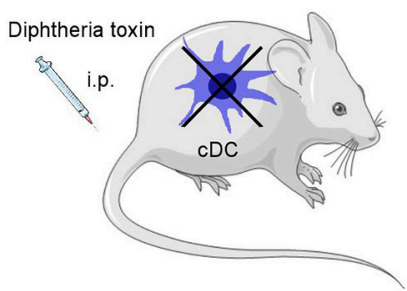

C Inducible pDC ablation

D Constitutive pDC ablation
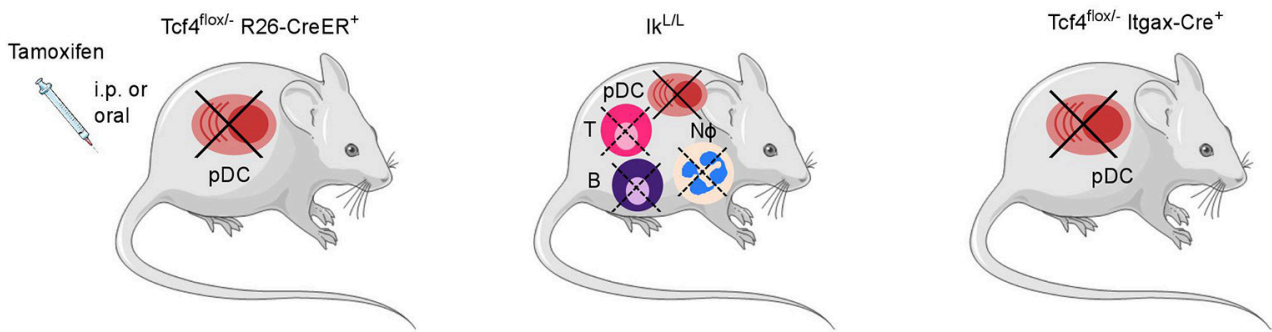

\section{E Restriction of type I IFN production to pDCs}

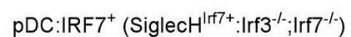

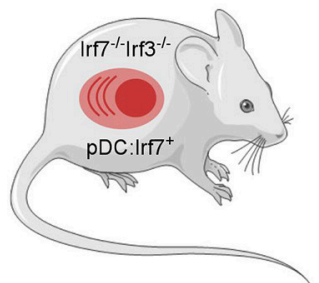

\section{F pDC-specific Cre expression}

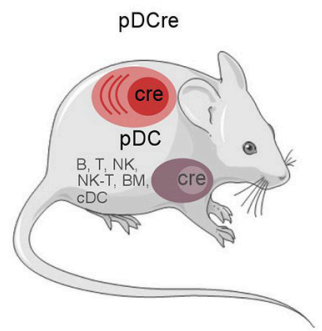

FIGURE 1 | Overview of genetically modified mouse models available to define the cellular source and impact of type I IFNs. (A) Reporter mouse models for the detection of type I IFN producing cells, (B) mouse strains for the transient DTR-mediated cell depletion and (C) inducible and (D) constitutive ablation of pDCs, (E) pDC-specific Cre expression, and (F) a mouse line with a restriction of the type I IFN production to pDCs have been employed in various infection settings in vivo. 
FIGURE 1 | Each model system harbors specific advantages and caveats as further described in Table 1. B, B cell; BM, bone marrow cell; cDC, conventional dendritic cell; MMM, marginal metallophilic macrophage; MZM, marginal zone macrophage; MO, monocyte; NK, natural killer cell; N $\varphi$, neutrophil; SSM, subcapsular sinus macrophage; T, T cell; pDC, plasmacytoid dendritic cell. The figure was created using Servier Medical Art according to Creative Commons Attribution 3.0 Unported License (https://creativecommons.org/licenses/by/3.0/). Changes were made to the original cartoons.

in type I IFN production. This yielded animals (referred to as "pDC:Irf7" mice) in which IRF7 signaling required for type I IFN expression is functional exclusively in pDCs (69). Additionally, in these mice an IRES site followed by coding sequences for Cre fused to the mutated ligand binding domain of the human estrogen receptor (ERT2) (103) was inserted behind the Irf7 gene into the Siglech gene locus (69). Therefore, this mouse line can potentially be used in the future for tamoxifen inducible pDC specific Cre expression and thus pDC specific gene deletion when crossed to the respective floxed mouse lines.

Also, for other cell types than pDCs, the DTR-mediated depletion approach has been employed. In recent years, mice expressing the DTR under the control of the CD11b-, CD11c-, and CD169-promoters have been generated and successfully used for depletion of monocytes, cDCs, and $\mathrm{CD}_{169^{+}}$macrophage subpopulations such as MZMs and subcapsular sinus macrophages in the spleen and lymph nodes (70-72, 104-109).

In the following sections we will discuss approaches designed to define the type I IFN producing cell types in infection using the in vivo mouse models described above.

\section{VIRAL INFECTIONS}

In this chapter we will focus on more recent findings from in vivo models aimed at visualizing IFN $\alpha / \beta$ producing cell types and defining their contribution to the overall type I IFN production and their impact on the course of viral infections (Table 2). For a more generalized overview of the cellular sources of type I IFN in viral infections we kindly refer to an expert review by Swiecki et al. (127).

\section{DNA Viruses}

Findings on the cellular sources of type I IFN during relevant infection models for DNA viruses and the respective in vivo experimental strategies are highlighted in the following sections.

\section{Human and Mouse Cytomegalovirus}

Infection with the human cytomegalovirus (HCMV) causes mostly asymptomatic, latent infections in the immunocompetent host. In immunosuppressed individuals or newborns infected in utero, an infection with this virus can lead to severe illness and permanent organ damage. The murine cytomegalovirus (MCMV) exhibits high structural and biological similarity to HCMV and is thus widely used as a model system for antiviral immune responses (128). MCMV induces a biphasic type I IFN response, with peak expressions occurring at $8 \mathrm{~h}$ and $36-72 \mathrm{~h}$ p.i. which are triggered by the initial virus contact and viral particles entering the system after completion of the first viral replication cycle, respectively (110). Early type I IFN expression is independent of TLR signaling and predominantly generated by stromal cells infected by the virus (110). Using IFN $\beta^{\text {mob/mob }}$ reporter mice, IFN $\beta$ production was detected in splenic $\mathrm{pDCs}$ as early as $6-12 \mathrm{~h}$ p.i. $(59,111)$. After in vivo depletion of pDCs by anti-CD317 or anti-Ly6G/C treatment IFN $\alpha$ serum levels were severely reduced $36 \mathrm{~h}$ after MCMV infection $(18,80,81,113)$. Under these conditions, however, other cell types secrete IL-12 and ensure sufficient IFN $\gamma$ and $\mathrm{NK}$ cell responses leading to control of MCMV infection $(18,80)$. Of note, $44 \mathrm{~h}$ after MCMV infection IFN $\alpha$ serum levels in $\mathrm{pDC}$ depleted mice were no longer reduced as compared to untreated mice (113). Similar observations were made in $\mathrm{Ik}^{\mathrm{L} / \mathrm{L}}$ mice that lack pDCs (61) or CLEC4A-DTR-tg mice that have been transiently depleted of pDCs $(65,113)$. Thus, transient type I IFN production at the first day of MCMV infection was pDC-dependent, while cells other than pDCs are responsible for the type I IFN levels measured at later timepoints, at least when relatively high inocula of MCMV are used. In contrast, at lower doses of MCMV which are presumably closer to a natural infection setting, pDCs can limit viral burden in the spleen and liver. Here, pDCs have been shown to promote NK cell activation and cytotoxicity in the early phase of MCMV infection (65). While it is well-established that pDCs sense the MCMV via the TLR9 and TLR7 mediated pathways $(18,80,113,129,130)$, also the TLR3 and TLR2 pathways which are functionally used by other cells than pDCs have been shown to be involved in the induction of type I IFN production $(104,131,132)$. These findings are in accordance with multiple observations that defects in MyD88 signaling have a more severe impact on anti-MCMV immune responses than TLR9 deficiency or pDC depletion $(113,129)$. So far, the identity of the non-pDC cell types involved in anti-MCMV type I IFN response remain incompletely defined.

\section{Vaccinia Virus}

One report indicated that vaccinia virus (VV) and to a lesser extend MCMV induce type I IFN in CD11c ${ }^{-} \mathrm{CD}_{11 \mathrm{~b}^{+}} \mathrm{Ly} \mathrm{C}^{+}$ inflammatory monocytes, but not macrophages or other types of DCs, in a TLR2 dependent way using IFN $\beta^{\text {mob/mob }}$ reporter mice. Further, CD11b-DTR-tg mice depleted of monocytes exhibited increased viral titers in the liver and decreased serum levels of type I IFN after VV infection (104). This is similar to other studies using footpad infection of modified vaccinia virus Ankara (MVA) and pDC depletion in the CLEC4A-DTR-tg mouse model, where type I IFN levels in the draining lymph nodes were comparable to control mice indicating that $\mathrm{pDCs}$ are not required for mounting an intact type I IFN response after local infection with this dsDNA virus (118).

\section{Adenovirus}

The dsDNA adenovirus is used as a vector for the development of gene therapy applications but can also cause severe disease in immunocompromised individuals. By using CD11c-DTR-tg 
TABLE 2 | Cellular sources of type I IFN production in viral infections in vivo.




TABLE 2 | Continued

\begin{tabular}{|c|c|c|c|}
\hline Virus & $\begin{array}{l}\text { Type I IFN } \\
\text { producing cells }\end{array}$ & Model systems and assay methods & $\begin{array}{l}\text { Observations in the absence } \\
\text { of cell type }\end{array}$ \\
\hline La Crosse virus & $\begin{array}{l}\text { Astrocytes, microglia, } \\
\text { neurons }\end{array}$ & 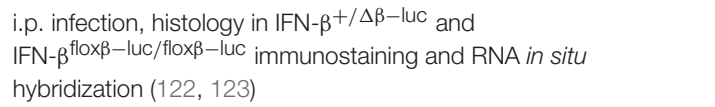 & n.d. \\
\hline \multirow[t]{2}{*}{$\begin{array}{l}\text { Newcastle disease virus } \\
\text { (NDV) }\end{array}$} & $\begin{array}{l}\text { pDCs, cDCs, } \\
\text { macrophages, monocytes }\end{array}$ & $\begin{array}{l}\text { systemic NDV infection, FACS analyses in Ifna6 } 9 f p /+ \text { reporter } \\
\text { mice (46) }\end{array}$ & n.d. \\
\hline & Alveolar macrophages & $\begin{array}{l}\text { intranasal NDV infection, FACS analyses in Ifna6gfp/+ reporter } \\
\text { mice (46) }\end{array}$ & n.d. \\
\hline Mouse hepatitis virus (MHV) & $\mathrm{pDCs}$ & $\begin{array}{l}\text { i.p. infection, pDC depletion anti-CD317 or absence of pDCs in } \\
\text { Itgax-Cre }{ }^{+} \operatorname{Tcf}^{\text {flox }}-{ }^{-} \text {mice }(100,124)\end{array}$ & $\begin{array}{l}\downarrow \text { IFN } \alpha \text { serum levels } \\
\uparrow \text { Viral titers increased } 48 \mathrm{~h} \text { p.i. }\end{array}$ \\
\hline \multirow{7}{*}{$\begin{array}{l}\text { Lymphocytic } \\
\text { choriomeningitis virus } \\
\text { (LCMV) }\end{array}$} & $\begin{array}{l}\text { pDCs (and macrophages } \\
\text { and cDCs) }\end{array}$ & WE, i.v. infection, 24-48 h p.i., Ifna6 ${ }^{g f p} /+$ reporter mice (76) & n.d. \\
\hline & Non-pDCs & $\begin{array}{l}\text { Armstrong and Clone13, i.v. infection, pDC depletion in } \\
\text { CLEC4A-DTR-tg mice }(65,125)\end{array}$ & $\begin{array}{l}\downarrow \text { IFN } \alpha \text { serum levels } 16 \mathrm{~h} \text { p.i. } \\
=\text { At later timepoints }\end{array}$ \\
\hline & Non-pDCs & $\begin{array}{l}\text { Armstrong and WE, i.v. infection, pDC depletion by anti-Ly6G/C or } \\
\text { absence of pDCs in Itgax-Cre }{ }^{+} \operatorname{Tcf} 4^{\text {flox } /-} \text { mice }(81,100)\end{array}$ & $\begin{array}{l}=\mathrm{IFN} \alpha \text { serum levels } 48 \mathrm{~h} \text { p.i., virus } \\
\text { cleared from organs day } 8 \text { p.i. }\end{array}$ \\
\hline & Non-pDCs & $\begin{array}{l}\text { Docile, i.v. infection, high dose, absence of pDCs in } \text { Itgax-Cre }^{+} \\
\text {Tcf }^{\text {flox }}-\text { mice }(100)\end{array}$ & Persistent serum virus titers \\
\hline & $\begin{array}{l}\text { Cells other than } \\
\text { macrophages }\end{array}$ & $\begin{array}{l}\text { WE, i.v., } 48 \mathrm{~h} \text { p.i., phagocyte depletion by clodronate liposomes, } \\
\text { FACS analysis IFN } \beta^{\text {mob/mob }} \text { mice (94) }\end{array}$ & $=\mathrm{IFN} \alpha$ serum levels \\
\hline & Phagocytic cells & $\begin{array}{l}\text { Armstrong, i.v., } 48 \text { h p.i., phagocyte depletion by clodronate } \\
\text { liposomes (95) }\end{array}$ & $\downarrow \downarrow$ IFN $\alpha$ serum levels \\
\hline & CD169+ macrophages & $\begin{array}{l}\text { marginal metallophilic macrophage and subcapsular sinus } \\
\text { macrophage depletion in CD169-DTR-tg mice }(72,107)\end{array}$ & $\begin{array}{l}\downarrow \text { Type I IFN from day } 4 \text { p.i. on, } \\
\text { persistent virus titers }\end{array}$ \\
\hline Chikungunya virus & pDCs & $\begin{array}{l}\text { s.c. infection, restriction of type I IFN expression to pDCs in } \\
\mathrm{pDC}: \operatorname{Irf} 7^{+} \text {mice (69) }\end{array}$ & $\begin{array}{l}\text { pDC:Irf7 }{ }^{+} \text {mice protected against } \\
\text { infection, } 100 \% \text { lethal in IRF3/7 } \\
\text { double deficient mice }\end{array}$ \\
\hline Dengue virus & $\begin{array}{l}\text { pDCs and cells other than } \\
\text { pDCs }\end{array}$ & $\begin{array}{l}\text { i.v. infection, restriction of type I IFN expression to pDCs in } \\
\text { pDC:Irf7 }{ }^{+} \text {mice (69) }\end{array}$ & $\begin{array}{l}\downarrow \text { Viral titers in pDC:Irf7 }{ }^{+} \text {as } \\
\text { compared to IRF3/7 double deficient } \\
\text { mice transiently } 42-72 \text { p p.i. }\end{array}$ \\
\hline $\begin{array}{l}\text { Respiratory syncytial virus } \\
\text { (RSV) }\end{array}$ & $\mathrm{pDCs}$ & Intratracheal infection, pDC depletion by anti-CD317 (126) & $\begin{array}{l}\uparrow \text { Viral titers } \\
\uparrow \text { Immunopathology in the lung day } 9 \\
\text { p.i., ø IFN } \alpha \text { production in the lung }\end{array}$ \\
\hline
\end{tabular}

mice and anti-CD317 treatment to ablate cDCs vs. pDCs in vivo it has been shown that wildtype (WT) adenovirus as well as adenoviral vectors induce rapid IFN $\alpha / \beta$ production almost exclusively in splenic cDCs rather than in pDCs (105).

\section{Herpes Simplex Virus}

For Herpes Simplex Virus (HSV) local (subcutaneous or genital) as well as systemic (i.v.) infection models have been analyzed. After subcutaneous HSV-1 infection, pDCs were shown to provide type I IFN necessary for licensing of $\mathrm{cDCs}$ which in turn induce effective cytotoxic $\mathrm{T}$ cell responses. Here, mice depleted for pDCs by anti-Ly6G/C treatment displayed increased viral titers in the draining lymph nodes at day 7 p.i. as compared to controls (82). Similarly, in a genital HSV-2 herpes model, mice depleted for pDCs using anti-CD317 antibodies succumbed earlier to the infection and exhibited reduced local IFN $\alpha$ levels, while the Th1 response in draining lymph nodes developed normally (117). In contrast to findings from antibodymediated depletion, in pDC depleted CLEC4A-DTR-tg mice neither differences in viral burden nor survival after vaginal HSV-2 infection was found nor were pDCs found to contribute significantly to antiviral CD8 T cell responses after subcutaneous HSV-1 inoculation (114). These contradicting findings have been explained by the antibody-mediated depletion of additional cell types other than pDCs in contrast to the more restricted depletion in the CLEC4A-DTR-tg genetic mouse model. On the other hand, it cannot be excluded that DTR mediated depletion is less effective and therefore a residual pDC activity retained after DT administration. Slight differences in the respective experimental settings might contribute as well as e.g. after antibody-mediated pDC depletion IFN $\alpha$ levels were measured in vaginal washes while in the genetic depletion model total protein amount was assessed in the vaginal and cervical tissue itself. As for MCMV, TLR3-expressing cells, such as CD8 ${ }^{+}$DCs or other hematopoietic and non-hematopoietic cells, are essential for type I IFN production in local HSV infection at later timepoints rather than pDCs (114).

After systemic challenge with UV-irradiated HSV in an early study immunohistological stainings for IFN $\alpha / \beta$ indicated that the majority of type I IFN producing cells in the spleen represent marginal metallophilic macrophages and to a lesser extend MZMs (133). However, IFN $\alpha$ levels were markedly reduced in 
pDC depleted Siglech ${ }^{\mathrm{dtr}} / \mathrm{dtr}$ mice $6 \mathrm{~h}$ after i.v. infection with HSV-1 and viral titers were found increased in the spleen as compared to control animals pointing toward pDCs as the major type I IFN producers in this situation (66). Similar results were obtained in pDC depleted CLEC4A-DTR-tg mice, with the exception that no viral replication was detectable in the spleens of either DT-treated CLEC4A-DTR-tg or control mice (114). This discrepancy may reflect differences in the strains of HSV-1 used or differences in the promoters used to drive DTR expression (CLEC4A vs. SiglecH) with a slightly divergent expression pattern as discussed above. For systemic HSV-2 infections, results from antibody depletion and pDC ablation in CLEC4A-DTRtg mice corresponded well since in both cases a reduction of IFN $\alpha$ serum levels were observed together with increased viral titers and reduced survival (114-116). Thus, similar to vaccinia virus the cell type responsible for the production of type I IFN in HSV infection may depend on the route of pathogen entry with pDCs controlling the infection once the virus has spread systemically.

\section{Ectromelia Virus}

Ectromelia virus (ECTV), a large DNA orthopoxvirus, is the causative agent of mousepox, the mouse homolog of human smallpox. ECTV causes systemic disease after s.c. infection of the footpad. In vivo it was shown by clodronate and anti-CD317 mediated depletion of monocytes vs. pDCs and ex vivo sorting and RT-PCR analyses that infected inflammatory monocytes are the major producers of type I IFN in the draining lymph nodes (119).

In summary, the cellular source for type I IFN production during DNA virus infection depends on the virus type itself, the dosage, timepoint as well as route of infection. Early after infection with MCMV pDCs are the primary source of type I IFN production capable of reducing virus titers at low concentrations of the virus. However, at later timepoints of infection $\mathrm{CD}^{+}$ DCs rather than pDCs become the key source of type I IFN production. In addition to $\mathrm{pDCs}$, other cell types such as $\mathrm{CDCs}$ in adenovirus infection, metallophilic macrophages and MZMs during HSV exposure, stromal cells in MCMV infection and inflammatory monocytes in response to ECTV are an essential source of type I IFN.

\section{RNA Viruses}

A recent meta-transcriptomics survey defined 196 vertebratespecific RNA virus species the majority of which is able to infect humans and cause diseases of varying severity $(134,135)$. At the moment only few mouse models are available to elucidate the host immune response to these viruses. In this chapter we summarize the in vivo model studies aimed at visualizing type I IFN producing cell types and defining their contribution to the type I IFN production and RNA virus control.

\section{Newcastle Disease Virus}

For systemic infections with RNA viruses, such as after i.v. inoculation with the paramyxovirus Newcastle disease virus (NDV), it has been shown that $\mathrm{pDCs}$ and also $\mathrm{cDCs}$, macrophages, and monocytes, produced IFN $\alpha$ (46). Here, pDCs mount an antiviral type I IFN response in a viral replicationindependent manner through virus recognition by TLR7 and the activation of the type I IFN positive feedback loop. Only in the absence of this type I IFN positive feedback, the virus infects and also replicates in pDCs. In this case, type I IFN induction occurs in pDCs via cytoplasmic RLHs (32). However, other ssRNA viruses have been reported to induce type I IFN expression in pDCs in a replication dependent manner (136, 137). Especially for vesicular stomatitis virus (VSV), the capture of the replicating virus in the autophagosome is required for its transfer to the TLR7 containing endosomal compartment (137). After local infection with NDV, here after intranasal infection, the IFN $\alpha$-producing cells shifted from pDCs to alveolar macrophages and cDCs that utilize the RLH system for type I IFN induction (46).

\section{Vesicular Stomatitis Virus}

Upon s.c. VSV infection, draining LNs contained 90\% less IFN $\alpha$ when depleted of macrophages by clodronate liposomes. However, when pDCs were depleted by anti-CD317 treatment, IFN $\alpha$ levels induced by VSV were reduced only by half as compared to controls. It was concluded that infected CD169 ${ }^{+}$ subcapsular sinus macrophages produce IFN $\alpha$, yet half of the type I IFN is produced by pDCs stimulated directly or indirectly by the infected macrophages (108). Later it was shown that $\mathrm{CD} 69^{+}$macrophages in the spleen represent a compartment of enhanced viral replication (138). Thus, it is conceivable that $\mathrm{CD}_{169^{+}}$macrophages potentiate the type I IFN response indeed indirectly via activating pDCs. When VSV was inoculated i.v. in CLEC4A-DTR-tg mice transiently depleted for $\mathrm{pDCs}$, IFN $\alpha$ was found reduced and viral titers increased only at very early timepoints, again pointing to a rather transient role of pDCs in anti-viral immunity (65).

\section{Dengue and Chikungunya Virus}

For the distantly related arboviruses Dengue (DENV) and Chikungunya (CHIKV) virus it was recently shown that $\mathrm{pDCs}$ are sufficient to control these viruses via IRF7-regulated type I IFN responses in both systemic as well as local infection settings. In this report novel $\mathrm{pDC}: \operatorname{Irf} 7^{+}$mice were introduced in which IRF7-driven type I IFN production is restricted to pDCs and were compared to IRF3/7 double deficient mice that are completely devoid of type I IFN expression (69). After i.v. infection with DENV pDC:Irf7 ${ }^{+}$mice exhibited a lower viral load than Irf3/7 double deficient mice. However, as compared to WT mice higher viral tiers were detected in $\mathrm{pDC}: \mathrm{Irf}^{+}{ }^{+}$mice (69). After s.c. infection with CHIKV Irf3/7 double deficient mice succumb to the virus while $100 \%$ of $\mathrm{pDC}$ : $\operatorname{Irf} 7^{+}$mice survive the infection exhibiting no overt clinical symptoms similar to WT mice. Early control of viremia in ${\mathrm{pDC}: \mathrm{Irf}^{+}}^{+}$mice was reduced as compared to WT but still improved as compared to $\operatorname{Irf3/7}$ double deficient mice. Thus, analogous to findings from other virus infection models also for these RNA viruses, antiviral response mounted by $\mathrm{pDCs}$ controls infection once the virus spreads systemically. 


\section{La Crosse Virus, Rabies Virus, and Theiler's Murine Encephalomyelitis Virus}

In infection models with RNA viruses exhibiting a specific tropism, pDCs play only a minor role. In the brain of mice infected with the ssRNA La Crosse virus, IFN $\beta$ production was assessed by the IFN- $\beta^{+/ \Delta \beta-\text { luc }}$ luciferase reporter mouse model (60) and detected in astrocytes, microglia, and to a lesser extend also in infected neurons (122). This confirmed earlier findings where IFN $\alpha / \beta$ expression in these cell types after La Crosse virus infection was visualized by immunostaining and RNA in situ hybridization (123). Utilizing the conditional reporter activity of the IFN- $\beta^{\text {flox } \beta-\text { luc } / \text { flox } \beta-\text { luc }}$ mice it was shown for several neurotropic viruses such as rabies virus (RABV), Theiler's murine encephalomyelitis virus (TMEV), and VSV that astrocytes are the main producers of IFN $\beta$ after infection of the brain (139).

\section{Encephalomyocarditis Virus}

Another example for type I IFN expression by non-myeloid cells represent $\beta$-islet cells. The encephalomyocarditis virus (EMCV) strain $\mathrm{D}$, an ssRNA picornavirus with tropism for the insulinproducing $\beta$ cells of the pancreas, can induce diabetes and myocarditis in certain mouse strains. CD $11 c^{+}$cells in this model have been shown to be protective as DT treated CD11c-DTR-tg mice developed diabetes and exhibited increased viral titers in the pancreas, spleen, and heart associated with reduced type I IFN levels as compared to non-depleted controls (106).

\section{Pneumonia Virus of Mice}

Pneumonia virus of mice (PVM) infection led to a marked infiltration of pDCs and increased expression of type I IFN in WT but not TLR7- or MyD88-deficient mice. Transfer of TLR7competent, but not TLR7-deficient pDCs led to a significantly diminished virus recovery in TLR7 ${ }^{-/}$animals on day 7 after infection with PVM indicating that TLR7-mediated signaling by $\mathrm{pDC}$ is required for appropriate innate responses to acute PVM infection (140).

\section{Respiratory Syncytial Virus}

For intratracheal infection with respiratory syncytial virus (RSV) it has been shown that anti-CD317 mediated depletion of pDCs completely abolished IFN $\alpha$ expression and protein levels in the lungs. This correlated with increased viral titers and exacerbated immunopathology of the lungs of pDC depleted mice (126). Thus, pDCs fulfill a substantial protective role during local RSV infection.

\section{Influenza Virus and Influenza Virus-Like Orthomyxovirus Thogoto Virus}

Initial in vitro studies showed that spleen cells from mice that were depleted for pDCs by anti-Ly6G/C injection did not produce IFN $\alpha$ in response to stimulation with inactivated influenza virus in contrast to splenocytes from untreated animals (18). IFN $\alpha$ production in vitro could be attributed to the CD317 ${ }^{+}$ CD11c ${ }^{+}$pDC population of sorted mouse spleen cells (86). However, in vivo intranasal infection with sublethal doses of influenza virus in $\mathrm{pDC}$-deficient $\mathrm{Ikaros}^{\mathrm{L} / \mathrm{L}}$ and WT mice revealed a similar course of disease, as determined e.g. by weight loss and viral titers (120). Thus, pDCs are able to produce type I IFN after stimulation by influenza but are dispensable for a successful antiviral immune response. Albeit, type I IFN levels in vivo were not assessed for this infection model.

For the influenza virus-like orthomyxovirus Thogoto virus (THOV) type I IFN production in the peritoneal cavity was mainly attributed to $\mathrm{CD} 1 \mathrm{~b}^{+} \mathrm{F} 4 / 80^{+}$myeloid cells that was independent of the type I IFN receptor mediated feedback loop and coincided with the tropism of this virus (121).

\section{Mouse Hepatitis Virus}

After i.p. infection with Mouse hepatitis virus (MHV), pDC depletion by anti-CD317 was accompanied by severely diminished IFN $\alpha$ serum levels (124). The transient pDC depletion did not lead to lethality following the low-dose MHV infection used in this study. Nevertheless, initial viral titers in spleens were found increased more than 1,000-fold in pDC-depleted compared to control mice (124). Very similar observations were made in Itgax-Cre ${ }^{+} \mathrm{Tcf} 4^{\text {flox } /-}$ mice lacking pDCs. These mice show reduced serum IFN $\alpha$ levels and elevated viral loads in the liver and spleen (100). Thus, pDCs appear to be essential for type IFN I mediated protection against systemic infection with the prototypical acute cytopathic coronavirus MHV.

\section{Lymphocytic Choriomeningitis Virus}

Lymphocytic choriomeningitis virus (LCMV) infection is widely used to study acute as well as chronic infections. In an acute infection setting in Ifna $6^{\mathrm{gfp} /+}$ reporter mice pDCs were found to be the major type I IFN producers after infection with the WE strain of LCMV. Additionally, few cDCs and macrophages specifically in the spleen exhibited GFP-reporter activity (76). Also, in IFN $\beta^{\text {mob/mob }}$ reporter mice macrophages could be excluded as major type I IFN producers and depletion of phagocytic cells by clodronate liposomes did not affect type I IFN serum levels (94). In contrast, another study using the Armstrong strain of LCMV reported severely reduced IFN $\alpha / \beta$ serum levels after clodronate treatment (95). Specifically, a small population of $\mathrm{CD} 69^{+}$macrophages in the spleen and lymph nodes has recently been shown to release high amounts of type I IFN after LCMV infection. Selective depletion of these cells in CD169-DTR-tg mice resulted in reduced type I IFN levels from day 4 p.i. onward and persistent viral titers. As a consequence, CD169 depleted mice exhibited severe immunopathology and died quickly after infection (107). In line with this, production of serum type I IFN was not reduced in LCMV infected mice treated with the pDC depleting anti-Ly6G/C antibody as compared to those injected with control antibody (81). Also, in congenitally pDC-deficient Itgax-Cre ${ }^{+}$Tcf $4^{\text {flox/- }}$ mice, virus titers early after infection were comparable to WT controls confirming that $\mathrm{pDCs}$ are dispensable for the control of acute LCMV infection (100). Still, pDCs have been shown to be a transient source of type I IFN as pDC depletion in CLEC4A-DTR-tg mice led to reduced serum IFN $\alpha$ levels at $16 \mathrm{~h}$ p.i. with LCMV Armstrong or clone 13, but not at later timepoints (125). Contrasting the observations in acute LCMV infection, in a chronic infection setup using LCMV 
Docile the virus persisted until day 53 in the blood of Itgax$\mathrm{Cre}^{+} \mathrm{Tcf} 4^{\text {flox/- }}$ mice while the virus was cleared between day 21 and 28 in WT mice. This was attributed to a failure of sufficient $\mathrm{CD}^{+}$and $\mathrm{CD} 8^{+} \mathrm{T}$ cell activation in the absence of $\mathrm{pDCs}$ and indicated that $\mathrm{pDCs}$ are essential for generating a functional adaptive immunity to chronic viral infections (100).

Taken together, pDCs are a major source of type I IFN and are required for type I IFN mediated protection against systemic infection in most of the RNA virus infections such as NDV, VSV, DENV, CHIKV, PVM, RSV, MHV, and LCMV. However, contribution of $\mathrm{pDCs}$ in type I IFN release and type I IFN mediated protection depends on the titer of the virus, time after infection, and the route of the infection. In addition to pDCs, other cell types such as cDCs, macrophages, and monocytes in $\mathrm{NDV}$, macrophages in VSV, astrocytes, microglia, and neurons in La Crosse virus, astrocytes in RABV, TMEV, and VSV, $\beta$-islet cells and $\mathrm{cDCs}$ in EMCV, and cDCs and macrophages in LCMV infection significantly contribute to type I IFN production. Thus, similar to infection with DNA viruses, also after infection with RNA viruses pDCs are functionally involved in type I IFN production mostly early during infection but are dispensable for virus control during later stages of infection. In chronic infection, however, pDCs provide type I IFN to support and preserve T cell functions.

\section{Retroviruses}

HIV activates pDCs to produce high levels of IFN $\alpha$ most likely via activation of TLR7 (141). Also, it is assumed that type I IFNs are produced during HIV infection predominantly by pDCs as decreased IFN $\alpha$ production in HIV-infected patients correlates with numerical and functional deficiencies in circulating pDCs (142). A direct assessment of the contribution of pDCs to type I IFN levels in HIV-infection, however, has not been performed. Although type I IFNs are known to mediate antiviral immunity, there has always been caution toward a detrimental role of type I IFNs during HIV/AIDS because of their proinflammatory nature $(11,143,144)$. Thus, many studies have shown that pDCs are a source of type I IFN in retroviral and other virus infections in vivo. However, additional cellular sources of type I IFN are required to fully control viral infections. In summary, pDCs are a known source of type I IFN in retroviral infection. However, the relative contribution of pDCs vs. other type I IFN producers to the overall type I IFN response and immune control or pathology after retrovirus infection, is not fully understood.

\section{BACTERIAL INFECTIONS}

While a considerable number of studies have been undertaken to define the cellular source of type I IFN and the functions of these cell types in viral infections, fewer data exist for non-viral infections. In bacterial infections, type I IFNs can act as activators of protective immune responses or mediate immunosuppressive functions leading to exacerbation of the infection. This ambivalent role of type I IFN has been reviewed recently $(1,11,145)$. In this chapter we will focus on the efforts to clarify the identity and impact of type I IFN producing cells as knowledge on these has increased significantly paralleling the availability of newly developed mouse models.

\section{Mycobacteria}

It has been well established that CD4 $\mathrm{T}$ cells as well as secreted effector cytokines TNF, IL-12, and IFN $\gamma$ exert protective functions in host resistance to the intracellular bacterial pathogen Mycobacterium tuberculosis (Mtb) (146). In contrast, the role of type I IFN during $M t b$ infection appears to promote infection instead of controlling infection. Type I IFNs downregulate IFNGR1 expression and thereby suppress IFN $\gamma$ signaling (147, 148) and IFNAR-deficient mice displayed increased bacterial clearance to infection with $M t b$, although bacterial growth in the lung was unaffected (149). In in vitro studies, BM-derived macrophages and DCs have been identified as a possible source of type I IFN in response to $M t b(149,150)$. Also, human peripheral blood mononuclear cell (PBMC)-derived macrophages and especially DCs were shown to produce type I IFN after in vitro infection with $M t b(151,152)$.

Similar to $M t b$, IFN $\gamma$ promotes antimicrobial activity against Mycobacterium leprae whereas type I IFNs contribute to pathogenesis (153). Here, PBMC-derived monocytes expressed IFN $\beta$ and IFN-stimulated genes including the immunosuppressive cytokine IL-10 during $M$. leprae infection in vitro (153). So far the cell type expressing type I IFN in the context of mycobacterial infections in vivo as well as definition of the functional impact of these cells await clarification.

\section{Listeria monocytogenes}

Type I IFN not only inhibits antibacterial signaling pathways and promotes infection in the case of mycobacteria. Also, $L$. monocytogenes has evolved mechanisms to activate the type I IFN pathway for the benefit of this intracellular pathogen. Mice deficient in IFNAR signaling are more resistant to systemic L. monocytogenes infection as compared to WT controls. Mechanistically, type I IFNs enhance susceptibility to systemic Listeria infection by reducing responsiveness to IFN $\gamma$, decreasing the number of pro-inflammatory myeloid cells, promoting the expression of proapoptotic genes, and enhancing $\mathrm{T}$ cell sensitivity to apoptosis $(148,154-156)$. Of note, in intragastric or foodborne infection with $L$. monocytogenes type I IFN receptor mediated signaling contributed positively to survival of infected mice or did not have an impact at all, respectively $(157,158)$. This emphasizes again, that the route of infection contributes significantly to differences in the impact of type I IFN in infection.

Four distinct cell types have been reported as sources for type I IFN production during systemic L. monocytogenes infection in vivo (Table 3). For one, a FACS-purified splenic cell population from infected mice that displays surface antigens typical of macrophages and not pDCs was identified as the main producer of type I IFN (159). Also, the apathogenic Listeria mutant lacking listeriolysin $\mathrm{O}$ which is unable to escape from the phagolysosome into the cytoplasm of the infected cell, does not stimulate IFN $\beta$ synthesis $(164,165)$. Later, Tip-DCs, an effector subtype of Mac$3^{\text {hi }}$ inflammatory monocytes, which produce TNF and iNOS were identified as the major IFN $\beta$-producing cells in vivo in 
systemic $L$. monocytogenes infections using IFN $\beta^{\text {mob/mob }}$ and IFN- $\beta^{+/ \Delta \beta-\text { luc }}$ reporter mice $(160,161)$. IFN $\beta$-producing TiPDCs harbored high bacterial loads and were located within the foci of infection in the splenic white pulp ideally positioned to activate T cells as well as NK cells via type I IFN (160). Bacterial loads in the spleen were severely increased in mice deficient in CCR2 and thus lacking TiP-DCs (162). Thus, this subtype of inflammatory monocytes has been attributed an important role in early containment of L. monocytogenes infection $(162,166)$. The overall role of TiP-DCs in this infection may therefore be ambiguous, having a regulatory function in controlling the balance between containment of infection and at the same time mediating detrimental effects of type I IFN on the host. Interestingly, in the spleens of Listeria-infected CCR2 $2^{-/}$mice increased levels of type I IFN were observed indicating that alternative cell types produce type I IFN in the absence of TiPDCs which are triggered additionally by increased bacterial load. Along this line, a detrimental role for pDCs in controlling $L$. monocytogenes infection was demonstrated in Siglech ${ }^{\mathrm{dtr} / \mathrm{dtr}}$ mice where ablation of pDCs caused significantly increased survival and decreased bacterial burden at day 3 p.i., while type I IFN levels themselves were not analyzed under these conditions (66). At earlier timepoints, however, anti-PDCA-1 mediated depletion of pDCs did not lead to a difference in bacterial load or levels of type I IFN in the spleen as compared to control animals (161). In one report, $\mathrm{CD} 317^{+}$SiglecH $^{-} \mathrm{CD} 19^{+} \mathrm{B}$ cells have been found to be able to induce IFN $\alpha$ after stimulation with heatkilled L. monocytogenes (163). Ex vivo isolated $\mathrm{CD}_{11} 7^{+}$SiglecH $^{-}$ $\mathrm{CD}^{+}{ }^{+} \mathrm{B}$ cells activated cytotoxic function of NK cells in an IFN $\alpha$-dependent manner. In vivo, this B cell subset contributed positively to resistance to L. monocytogenes infection as Btk ${ }^{-/-}$ mice deficient for B-cells and unable to generate $\mathrm{CD} 317^{+} \mathrm{CD} 19^{+}$ B cells displayed increased susceptibility to L. monocytogenes infection, while adoptive transfer of $\mathrm{CD} 317^{+} \mathrm{CD} 19^{+} \mathrm{B}$ cells to $\mathrm{Btk}^{-/-}$mice normalized their resistance to L. monocytogenes infection (163).

\section{Extracellular Bacteria}

As for intracellular bacteria also for extracellularly replicating bacterial pathogens type I IFN can either be detrimental or essential for host defense (145). Group B streptococci (GBS) are important neonatal pathogens and type I IFN receptor signaling is reported to contribute to host resistance against this pathogen (167). Mice i.p. infected with GBS express elevated levels of IFN $\beta$ and IFN $\alpha 4$ mRNA in the spleen. In vitro, GBS activated type I IFN expression in peritoneal macrophages, BMderived cDCs and to a lesser extent also in macrophages, while pDCs were completely unable to produce type I IFN after GBS stimulation $(167,168)$.

In contrast to GBS, type I IFN induction in the mixed bacterial sepsis model of colon ascendens stent peritonitis (CASP) has been shown to have a detrimental effect on the host. Septic peritonitis induced in $\mathrm{IFNAR}^{-/-}$mice showed improved survival and bacterial clearance as compared to WT controls. Splenic CD $11 b^{+} \mathrm{CD} 11 c^{-}$macrophage-like cells could be identified as major producers of IFN $\beta$ ex vivo by
TABLE 3 | Cellular sources of type I IFN production in Listeria monocytogenes infection in vivo.

\begin{tabular}{|c|c|c|}
\hline $\begin{array}{l}\text { Type I IFN producing } \\
\text { cells }\end{array}$ & $\begin{array}{l}\text { Model systems and assay } \\
\text { methods }\end{array}$ & $\begin{array}{l}\text { Observations in } \\
\text { the absence of } \\
\text { cell type }\end{array}$ \\
\hline Macrophages & $\begin{array}{l}\text { i.p. infection, RT-PCR for type I } \\
\text { IFN from ex vivo FACS sorted cell } \\
\text { populations (159) }\end{array}$ & n.d. \\
\hline Tip-DCs & $\begin{array}{l}\text { i.v. and i.p. infection, FACS } \\
\text { analysis and histology in } \\
\text { IFN } \beta^{\text {mob } / m o b} \text { and luciferase } \\
\text { activity in IFN- } \beta^{+/ \Delta \beta-l u c} \text { reporter } \\
\text { mice }(59,60,160,161)\end{array}$ & n.d. \\
\hline Non-TiP-DCs & $\begin{array}{l}\text { i.v. infection, TiP-DC deficient } \\
\text { CCR2 }{ }^{-/-} \text {mice (162) }\end{array}$ & $\begin{array}{l}\uparrow \text { Bacterial load } \\
\uparrow \text { Type I IFN in the } \\
\text { spleen }\end{array}$ \\
\hline pDCs & $\begin{array}{l}\text { i.p. infection, pDC depletion in } \\
\text { Siglech }^{\text {dtr} / d t r} \text { mice (66) }\end{array}$ & $\begin{array}{l}\uparrow \text { Survival } \\
\downarrow \text { Proinflammatory } \\
\text { cytokines }\end{array}$ \\
\hline $\begin{array}{l}\mathrm{PDCA}-1^{+} \text {SiglecH } \\
\mathrm{CD}^{-} 9^{+} \mathrm{B} \text { cells }\end{array}$ & $\begin{array}{l}\text { i.p. infection, B cell deficient } \\
\text { Btk }^{-/-} \text {mice }(163)\end{array}$ & $\downarrow$ Survival \\
\hline
\end{tabular}

RT-PCR analyses from sorted cells, while no IFN $\alpha$ subtypes were detected (169).

In summary, type I IFN production has a detrimental effect for the host after infection with intracellular bacteria such as mycobacteria and L. monocytogenes. BMDCs and PBMC-derived DCs and macrophages are the responsible cell types for type I IFN production during mycobacteria infection. For L. monocytogenes, four cell types have been identified as type I IFN producers, namely macrophages, Tip-DCs, inflammatory monocytes, and B cells. In the case of extracellular bacteria, the cell types identified as type I IFN producers include macrophages and BMDCs. However, with the exception of the intracellular model organism L. monocytogenes, the knowledge on the cellular source of type I IFN in bacterial infection is rather scarce.

\section{FUNGAL INFECTIONS}

As for bacterial infections, the effect of type I IFN in mouse models for infections with pathogenic fungi has been reported as beneficial or detrimental for the host depending on the fungal species and the route of infection. Additionally, controversial results obtained from very similar infection settings have been explained by the possible impact of differences in the microbiome in the respective mouse colonies $(1,11)$. The cell type responsible for type I IFN production in fungal infections in vivo, however, awaits clarification. To our knowledge only for the important opportunistic fungal pathogen Aspergillus fumigatus in vivo studies in this direction have been undertaken. The type I IFN response triggered by $A$. fumigatus was analyzed initially in human pDCs isolated from PBMCs. When these cells were stimulated in vitro with A. fumigatus hyphae IFN $\alpha$ was detected in the supernatant (170). IFNAR ${ }^{-/-}$mice or mice depleted of pDCs by anti-CD317 treatment exhibited an increased susceptibility to pulmonary or i.v. infection with A. fumigatus 
conidia. A direct impact of pDC depletion on type I IFN levels in vivo after infection, however, has not been analyzed in this study (170). Therefore, the hypothesis that $\mathrm{pDCs}$ mediate their protective function in this fungal infection directly via type I IFN remains to be tested.

\section{INFECTIONS WITH PROTOZOAN PARASITES}

Infection with a wide variety of protozoan parasites can trigger type I IFN expression in mammalian hosts as reviewed recently $(171,172)$. For Plasmodium, Leishmania, and Trypanosoma in vivo infection models several studies have been carried out in the last few years which allowed the identification of cellular sources of type I IFN in response to intracellular parasite infections. This will be the focus of the following chapter and summarized in Table 4.

\section{Plasmodium}

Malaria is an important parasitic disease predominantly in tropical and subtropical African regions. It is caused by the protozoan parasite Plasmodium with $P$. falciparum being responsible for its most severe forms. In humans, malarial parasites are transmitted at sporozoite-stage by infected mosquitoes (182). The transmitted sporozoites rapidly travel to the liver, where they infect hepatocytes and initiate clinically silent but immunologically active liver-stage infection (171). Well-established in vivo mouse models include the lethal Plasmodium yoelii YM and $P$. berghei ANKA leading to high parasitemia and cerebral malaria (CM), respectively, after inoculation with Plasmodium-infected erythrocytes. Further, $P$. chabaudi is used as a chronic infection model. Various cellular sources for type I IFNs have been proposed after Plasmodium infection in vitro (182-184).

After inoculation with P. berghei ANKA infected erythrocytes in vivo, isolated splenic pDCs as well as $\mathrm{CD} 8^{-} \mathrm{cDCs}$ expressed type I IFN $(173,174)$. Using anti-CD317 mediated pDC depletion and CDC depletion in CD11c-DTR-tg mice it was shown that cDCs but not pDCs are required for the induction of $\mathrm{CM}$ (173). Additionally, cDCs require IFNAR dependent signaling for systemic IFN $\alpha$ production in this model as indicated by substantially lower levels of serum IFN $\alpha$ in CD11c-Cre Ifnar $\mathrm{f}^{\mathrm{fl} / \mathrm{fl}}$ mice, compared to those in infected Ifnar ${ }^{f l / f l}$ littermate controls (174).

In contrast to the $P$. berghei ANKA model, $P$. chabaudi infection did not induce IFN $\alpha$ in splenic cDCs but rather in pDCs via the TLR9 sensing pathway (175). However, pDCs were not essential for parasite clearance in $P$. chabaudi infection (175). Direct in vivo analysis performed in IFN $\beta^{\mathrm{mob} / \mathrm{mob}}$ reporter mice (59) revealed that in P. chabaudi infection about $75 \%$ of IFN producing cells are pDCs (176). In addition to pDCs, splenic red pulp macrophages (RPMs) can generate significant quantities of IFN $\beta$ in response to $P$. chabaudi infection. Contribution of both cell types to the type I IFN response in this system was defined by pDC depletion via anti-CD317 treatment and in RPM deficient $\mathrm{SpiC}^{-/-}$mice (176).
In the lethal malaria mouse model of $P$. yoelii $Y M$ infection, type I IFN enhances inflammatory blood leukocyte activation and lethal outcome (177). IFN $\beta^{\mathrm{mob} / \mathrm{mob}}$ reporter mice indicated here that type I IFN is produced in high amounts by BM and blood $\mathrm{pDCs}$ and to lesser extent by tissue resident $\mathrm{pDCs}$ (177). Depletion of pDCs by anti-CD317 or using pDC specific CLEC4A-DTR-tg mice confirmed pDCs as the major cellular source of type I IFN in this severe malaria model (177, 178). However, depletion of pDCs also resulted in a slight but significant increase of parasitemia (178). Further, priming of $\mathrm{pDCs}$ by plasmodium activated $\mathrm{CD} 169^{+}$macrophages was essential (177). It was proposed that in in vivo settings the low levels of secreted type I IFN produced by monocytes and macrophages prime pDCs for systemic production of type I IFN in malaria.

From data available so far, pDCs as well as cDCs and macrophage subtypes are the cell types responsible for the generation of the type I IFN response, depending on the Plasmodium species. Similar to LCMV, Mycobacteria, or Listeria infections $(153,156,185)$, it is thought that early robust production of type I IFN in the first $24 \mathrm{~h}$ is essential to induce protective innate and adaptive immunity against Plasmodium, while late production of type I IFN impairs host anti-malaria immune responses by induction of negative immune regulators such as PD-L1 and IL-10 (178).

\section{Leishmania}

Leishmania spp. are transmitted to mammalian organisms by the bite of infected sand flies (186). The parasites preferentially infect macrophages, but can also be found in other cell types, such as fibroblasts, neutrophils, and DCs (172). Depending on the parasite species and strain Leishmania causes a mild to severe cutaneous, mucocutaneous or visceral leishmaniasis $(171,187)$. Increased production of type I IFN has been observed in local tissues and in the draining lymph nodes of $L$. major infected mice $(187,188)$. There are diverging reports about the role of type I IFN production in the control of parasite burden and development of disease pathology. Depending on the time course of infection and type I IFN induction it can exert detrimental or protective effects for the host in Leishmaniasis (189). Most of the studies addressing the cellular source of type I IFN in Leishmania infection were performed in vitro. For example, infection of murine macrophages with $L$. major or L. amazonensis lead to type I IFN production $(188,190)$. In vitro exposure of BM-derived as well as splenic pDCs to L. major, L. infantum, or L. braziliensis promastigotes induces release of IFN $\alpha$ and IFN $\beta$ in a TLR9dependent manner (191). Intriguingly, the amounts of type I IFN produced in response to Leishmania spp. are comparable to the type I IFN levels produced in response to stimulation with CpG ODNs in these experiments (191). Recently in vitro exposure to the parasite $L$. donovani was reported to trigger IFN $\beta$ production in splenic B cells. Here, also high levels of type I IFN mRNA were detected in splenic B cells purified from in vivo $L$. donovani infected mice (179). Taken together, depending on the Leishmania subtypes, $\mathrm{pDCs}$ and $\mathrm{B}$ cells are the source of type I IFN when the cells are directly exposed to the pathogen in vitro. Information on the type I IFN producers in vivo remain 
TABLE 4 | Cellular sources of type I IFN production in intracellular parasite infections in vivo.

\begin{tabular}{|c|c|c|c|}
\hline Parasite & Type I IFN producing cells & Model systems and assay methods & $\begin{array}{l}\text { Observations in the } \\
\text { absence of cell type }\end{array}$ \\
\hline \multirow[t]{2}{*}{ Plasmodium berghei ANKA } & $\mathrm{pDCs}$ and $\left(\mathrm{CD}^{-}\right) \mathrm{cDCs}$ & RT-PCR from ex vivo purified splenic pDCs and cDCs $(173,174)$ & n.d. \\
\hline & cDCs & $\begin{array}{l}\text { Phagocyte depletion by clodronate liposomes, cDC specific IFNAR } \\
\text { deficiency in CD11c-Cre Ifnar } 1^{\mathrm{fl} / \mathrm{fl}} \text { mice }\end{array}$ & $\downarrow$ IFN $\alpha$ serum levels \\
\hline \multirow[t]{2}{*}{ Plasmodium chabaudi } & $\mathrm{pDCs}$ & $\begin{array}{l}\text { RT-PCR for type I IFN from ex vivo purified splenic pDCs; pDC } \\
\text { depletion by anti-CD317 (175) }\end{array}$ & $=$ Parasite clearance \\
\hline & $\begin{array}{l}\text { pDCs and red pulp } \\
\text { macrophages (RPMs) }\end{array}$ & $\begin{array}{l}\text { FACS analysis in IFN } \beta^{\text {mob/mob }} \text { reporter mice, RT-PCR from ex vivo } \\
\text { purified splenic cell populations, pDCs; pDC depletion by anti-CD317, } \\
\text { RPM deficient SpiC }-/- \text { mice (176) }\end{array}$ & $\begin{array}{l}\downarrow \text { IFN } \alpha \text { levels in the spleen } \\
=\text { Parasite clearance }\end{array}$ \\
\hline Plasmodium yoelii YM & pDCs & $\begin{array}{l}\text { FACS analysis in IFN } \beta^{\text {mob/mob }} \text { reporter mice }(59,177) \text {, pDC depletion } \\
\text { by anti-CD317 (178) or CLEC4A-DTR-tg mice }(65,177)\end{array}$ & $\begin{array}{l}\downarrow \text { IFN } \alpha \text { serum levels, } \uparrow \\
\text { Parasitemia }\end{array}$ \\
\hline Leishmania donovani & B cells & RT-PCR for type I IFN from ex vivo purified B cells (179) & n.d. \\
\hline \multirow[t]{2}{*}{ Toxoplasma gondii } & $\begin{array}{l}\text { Intestinal epithelial or lamina } \\
\text { propria cells }\end{array}$ & $\begin{array}{l}\text { RT-PCR for type I IFN from ex vivo purified intestinal epithelial or lamina } \\
\text { propria cells (180) }\end{array}$ & n.d. \\
\hline & Inflammatory monocytes & RT-PCR for type I IFN from ex vivo depleted cell populations (181) & n.d. \\
\hline
\end{tabular}

scarce so far for this important protozoan parasite model but could be increased significantly making use of the now available mouse models.

\section{Toxoplasma}

Toxoplasma gondii is an intracellular protozoan parasite that has infected at least $50 \%$ of the human population. It causes severe toxoplasmosis in immune-suppressed patients. T. gondii can infect a wide range of warm-blooded animals, is able to invade any nucleated cell but survives outside of the mammalian host as well $(171,172)$. The gut epithelium is a strategic barrier to prevent or limit parasite dissemination upon oral infection with $T$. gondii. In the initial phase of oral T. gondii infection elevated IFN $\beta$ mRNA levels were observed in the small intestine. Intestinal epithelial cells (IECs) and cells from the lamina propria are the source of local IFN $\beta$ production in early infection as assessed by real-time PCR performed on cells isolated from infected mice (180). In in vitro infection, T. gondii has been reported to induce or suppress type I IFN induction depending on the host species, the cell type, and the parasite strain analyzed. One publication showed that BMderived murine $\mathrm{pDCs}$ produce IFN $\alpha$ after infection with $T$. gondii (192). Murine pDCs recognized T. gondii profilin via TLR11 and TLR12 and produce type I IFN in a MyD88 dependent fashion $(192,193)$. In contrast to murine pDCs, human pDCs lack TLR11 and TLR12 and are unable to produce type I IFN despite of direct infection with $T$. gondii. Active infection with T. gondii in vitro rather functionally inactivates human pDCs (194). In particular macrophages and DCs serve as reservoirs of T. gondii infection and facilitate early dissemination (195). Most of the Toxoplasma strains tested are unable to induce type I IFN production in murine BM-derived macrophages after in vitro infection $(196,197)$. T. gondii mediated suppression of type I IFN expression has been reported also for monocytes, macrophages, and several DC subsets in vitro $(181,195,196)$. On the other hand, few atypical Toxoplasma strains such as
COUGAR and RUB can induce IFN $\beta$ production in murine BMderived macrophages as well as in human skin fibroblasts in in vitro infection systems (196). In a physiological oral infection mouse model ex vivo isolated inflammatory monocytes in the gut-draining mesenteric lymph nodes were identified the major producers of IFN $\beta$. The expression of IFN $\beta$ by inflammatory monocytes required phagocytic uptake of $T$. gondii, while active invasion did not trigger IFN $\beta$ induction (181). Thus, depending on the host species, the cell type, and the parasite strain, T. gondii may induce or suppress type I IFN production. Epithelial, skin fibroblasts, pDCs, macrophages and inflammatory monocytes here are known cellular sources of type I IFN. In T. gondii infection most of the knowledge about the cellular sources of type I IFN is deduced from in vitro experiments. Analysis of type I IFN reporter mouse models with and without ablation of different cell types is missing, so far.

Taken together, the major type I IFN producing cell types and their contribution to immunity against many protozoan parasites remain to be defined. To our knowledge, no direct study to elucidate the cellular sources of type I IFN in multicellular parasite such as helminth infections in vivo has been published. In order to understand the cellular sources of type I IFN and their relevance with regard to disease elimination in multicellular parasites such as helminths, type I IFN reporter mouse models and cell specific depletion models remain to be analyzed. As for the other pathogen types reviewed above, parasite numbers and the site of infection might influence the sensing pathway and cell type activated to produce type I IFN.

\section{CONCLUDING REMARKS AND FUTURE PERSPECTIVES}

In recent years the generation of novel animal models has remarkably advanced our understanding of the mode of action of IFNs and the cell type responsible for its production in the context of an infection. The existing knowledge does not allow to depict any cell type as a single cell type responsible for the 
entire type I IFN production in the course of any infection. Rather, depending on the type of infection a wide variety of cells have exhibited the capacity to produce type I IFN. Decisive factors for the type of cell initiating type I IFN production are the type and amount of pathogen and the site and stage of the infection. Additionally, the genetic background of the mouse model and its microbiome status contribute as well and need to be further analyzed.

Even though pDCs are more specialized than other cell types in type I IFN production, it is getting increasingly clear that in vivo their contribution to antiviral immunity and also to immune responses to bacterial, fungal, and parasitic infection exhibits restricted patterns in time of induction and duration. The importance of pDCs as the source of type I IFN early in virus infections does not hold true at later timepoints when other host cells take over as dominant producers of type I IFNs. The impact of pDCs also depends on the route of infection. While pDCs provide an important source of type I IFN in systemic infections, their requirement for I IFNmediated antiviral immune responses in local tissues seems to be necessary only if other lines of defense are broken. However, there are exceptions to the rule as shown for local infections with $\mathrm{MHV}$ and HSV-2 where pDC-derived type I IFN in mice is critical for viral control and survival. Indeed, the limitation of pDC responses is caused by an upregulation of pro-apoptotic molecules and apoptosis induction in $\mathrm{pDCs}$ in a type I IFN-dependent manner during systemic viral infections (198). This has been suggested as a mechanism to prevent immunopathology due to sustained pDC-mediated type I IFN production. Besides pDCs, mainly macrophages, inflammatory monocytes and cDCs are able to mount significant anti-infectious type I IFN responses in vivo. Instead of a single specialized cell type, it is rather the orchestrated type I IFN expression by multiple cellular sources that ensures protective anti-infectious immune responses mediated by type I IFN. To elucidate synergisms and redundancies between the different type I IFN producing cells will be a topic of future studies.

\section{REFERENCES}

1. McNab F, Mayer-Barber K, Sher A, Wack A, O'Garra A. Type I interferons in infectious disease. Nat Rev Immunol. (2015) 15:87-103. doi: 10.1038/nri3787

2. Kretschmer S, Lee-Kirsch MA. Type I interferon-mediated autoinflammation and autoimmunity. Curr Opin Immunol. (2017) 49:96-102. doi: 10.1016/j.coi.2017.09.003

3. Decker $T$, Muller M, Stockinger S. The yin and yang of type I interferon activity in bacterial infection. Nat Rev Immunol. (2005) 5:675-87. doi: $10.1038 /$ nri1684

4. Hardy MP, Owczarek CM, Jermiin LS, Ejdeback M, Hertzog PJ. Characterization of the type I interferon locus and identification of novel genes. Genomics. (2004) 84:331-45. doi: 10.1016/j.ygeno.2004.03.003

5. Platanias LC. Mechanisms of type-I- and type-II-interferon-mediated signalling. Nat Rev Immunol. (2005) 5:375-86. doi: 10.1038/nri1604

6. van Pesch V, Lanaya H, Renauld JC, Michiels T. Characterization of the murine alpha interferon gene family. J Virol. (2004) 78:8219-28. doi: 10.1128/JVI.78.15.8219-8228.2004

7. Honda K, Takaoka A, Taniguchi T. Type I interferon [corrected] gene induction by the interferon regulatory factor family of transcription
Advanced single cell functional profiling and systems biology approaches will contribute significantly in the near future to identify the exact functions of specific cell types, even cell subtypes, in the different stages of an infection. The spatiotemporal interaction of the type I IFN producing cell with the pathogen and the immune cells that are activated by type I IFN could help to better dissect the diverse functions of type I IFN in the immune response at different stages of infection. Importantly, due to the severe side effects of type I IFN treatment, there is a dire need to better control its activity and thereby increase its beneficial net effect. Strategies such as modifying the affinity of type I IFNs or modulating its time of availability have been reviewed recently (199). These new approaches to develop and improve vaccination strategies and to define novel therapeutic leads for infectious diseases are urgently called for in a time where antibiotic resistances are projected to increase rapidly.

\section{AUTHOR CONTRIBUTIONS}

SA, RM-N, AS, LR, JA, and SS wrote the manuscript. SA, $\mathrm{RM}-\mathrm{N}$, and SS designed and generated tables. RM-N designed and generated the figure. All authors read and approved the final manuscript.

\section{FUNDING}

This work was supported by the Deutsche Forschungsgemeinschaft (RTG 2158 Natural products and natural product analogs against therapy-resistant tumors and microorganisms: new lead structures and modes of action), the Manchot Graduate School Molecules of Infection II and III, the Research Commission of the Medical Faculty of the University of Düsseldorf, Germany (30/2016) (to SS) and by the Deutsche Forschungsgemeinschaft (FOR 2107, AL 1145/5-2), the IZKF (Alf3/018/16), the DFG EXC 1003, Grant FF-2014-01 Cells in Motion-Cluster of Excellence, Münster, Germany, and the Alzheimer Forschung Initiative e.V. (14835) (to JA).

factors. Immunity. (2006) 25:349-60. doi: 10.1016/j.immuni.2006 08.009

8. Ivashkiv LB, Donlin LT. Regulation of type I interferon responses. Nat Rev Immunol. (2014) 14:36-49. doi: 10.1038/nri3581

9. Schneider WM, Chevillotte MD, Rice CM. Interferon-stimulated genes: a complex web of host defenses. Annu Rev Immunol. (2014) 32:513-45. doi: 10.1146/annurev-immunol-032713-120231

10. Trinchieri G. Type I interferon: friend or foe? J Exp Med. (2010) 207:2053-63. doi: 10.1084/jem.20101664

11. Stifter SA, Feng CG. Interfering with immunity: detrimental role of type I IFNs during infection. J Immunol. (2015) 194:2455-65. doi: 10.4049/jimmunol.1402794

12. Isaacs A, Lindenmann J. Virus interference. I. The interferon. Proc $R$ Soc Lond B Biol Sci. (1957) 147:258-67. doi: 10.1098/rspb.1957. 0048

13. Theofilopoulos AN, Baccala R, Beutler B, Kono DH. Type I interferons (alpha/beta) in immunity and autoimmunity. Annu Rev Immunol. (2005) 23:307-36. doi: 10.1146/annurev.immunol.23.021704.115843

14. Cella M, Jarrossay D, Facchetti F, Alebardi O, Nakajima H, Lanzavecchia A, et al. Plasmacytoid monocytes migrate to inflamed lymph nodes and 
produce large amounts of type I interferon. Nat Med. (1999) 5:919-23. doi: $10.1038 / 11360$

15. Ito $\mathrm{T}$, Kanzler H, Duramad O, Cao W, Liu YJ. Specialization, kinetics, and repertoire of type 1 interferon responses by human plasmacytoid predendritic cells. Blood. (2006) 107:2423-31. doi: 10.1182/blood-2005-07-2709

16. Trinchieri G, Santoli D. Anti-viral activity induced by culturing lymphocytes with tumor-derived or virus-transformed cells. Enhancement of human natural killer cell activity by interferon and antagonistic inhibition of susceptibility of target cells to lysis. J Exp Med. (1978) 147:1314-33. doi: 10.1084/jem.147.5.1314

17. Trinchieri G, Santoli D, Dee RR, Knowles BB. Anti-viral activity induced by culturing lymphocytes with tumor-derived or virus-transformed cells. Identification of the anti-viral activity as interferon and characterization of the human effector lymphocyte subpopulation. J Exp Med. (1978) 147:1299313. doi: $10.1084 /$ jem.147.5.1299

18. Asselin-Paturel C, Boonstra A, Dalod M, Durand I, Yessaad N, DezutterDambuyant $\mathrm{C}$, et al. Mouse type I IFN-producing cells are immature APCs with plasmacytoid morphology. Nat Immunol. (2001) 2:1144-50. doi: $10.1038 /$ ni736

19. Bjorck P. Isolation and characterization of plasmacytoid dendritic cells from Flt3 ligand and granulocyte-macrophage colony-stimulating factor-treated mice. Blood. (2001) 98:3520-6. doi: 10.1182/blood.V98.13.3520

20. Nakano H, Yanagita M, Gunn MD. CD11c(+)B220(+)Gr-1(+) cells in mouse lymph nodes and spleen display characteristics of plasmacytoid dendritic cells. J Exp Med. (2001) 194:1171-8. doi: 10.1084/jem.194.8.1171

21. Blasius AL, Beutler B. Intracellular toll-like receptors. Immunity. (2010) 32:305-15. doi: 10.1016/j.immuni.2010.03.012

22. Kawai T, Akira S. The role of pattern-recognition receptors in innate immunity: update on Toll-like receptors. Nat Immunol. (2010) 11:373-84. doi: 10.1038/ni.1863

23. Reizis B, Bunin A, Ghosh HS, Lewis KL, Sisirak V. Plasmacytoid dendritic cells: recent progress and open questions. Annu Rev Immunol. (2011) 29:163-83. doi: 10.1146/annurev-immunol-031210-101345

24. Kawai T, Sato S, Ishii KJ, Coban C, Hemmi H, Yamamoto M, et al. Interferon-alpha induction through Toll-like receptors involves a direct interaction of IRF7 with MyD88 and TRAF6. Nat Immunol. (2004) 5:1061-8. doi: $10.1038 /$ ni1118

25. Guiducci C, Ott G, Chan JH, Damon E, Calacsan C, Matray T, et al. Properties regulating the nature of the plasmacytoid dendritic cell response to Toll-like receptor 9 activation. J Exp Med. (2006) 203:1999-2008. doi: $10.1084 / \mathrm{jem} .20060401$

26. Honda K, Ohba Y, Yanai H, Negishi H, Mizutani T, Takaoka A, et al. Spatiotemporal regulation of MyD88-IRF-7 signalling for robust type-I interferon induction. Nature. (2005) 434:1035-40. doi: 10.1038/nature03547

27. Gururajan M, Jacob J, Pulendran B. Toll-like receptor expression and responsiveness of distinct murine splenic and mucosal B-cell subsets. PLoS ONE. (2007) 2:e863. doi: 10.1371/journal.pone.0000863

28. Iwasaki A, Medzhitov R. Toll-like receptor control of the adaptive immune responses. Nat Immunol. (2004) 5:987-95. doi: 10.1038/ni1112

29. Akkaya M, Akkaya B, Miozzo P, Rawat M, Pena M, Sheehan PW, et al. B cells produce Type 1 IFNs in response to the TLR9 agonist CpG-A conjugated to cationic lipids. J Immunol. (2017) 199:931-40. doi: 10.4049/jimmunol.1700348

30. Barchet W, Cella M, Odermatt B, Asselin-Paturel C, Colonna M, Kalinke $\mathrm{U}$. Virus-induced interferon alpha production by a dendritic cell subset in the absence of feedback signaling in vivo. J Exp Med. (2002) 195:507-16. doi: 10.1084/jem.20011666

31. Asselin-Paturel C, Brizard G, Chemin K, Boonstra A, O'Garra A, Vicari A, et al. Type I interferon dependence of plasmacytoid dendritic cell activation and migration. J Exp Med. (2005) 201:1157-67. doi: 10.1084/jem.20041930

32. Kumagai Y, Kumar H, Koyama S, Kawai T, Takeuchi O, Akira S. Cutting Edge: TLR-dependent viral recognition along with type I IFN positive feedback signaling masks the requirement of viral replication for IFN-\{alpha\} production in plasmacytoid dendritic cells. J Immunol. (2009) 182:3960-4. doi: $10.4049 /$ jimmunol.0804315
33. Heil F, Hemmi H, Hochrein H, Ampenberger F, Kirschning C, Akira S, et al. Species-specific recognition of single-stranded RNA via toll-like receptor 7 and 8. Science. (2004) 303:1526-9. doi: 10.1126/science.1093620

34. Jurk M, Heil F, Vollmer J, Schetter C, Krieg AM, Wagner H, et al. Human TLR7 or TLR8 independently confer responsiveness to the antiviral compound R-848. Nat Immunol. (2002) 3:499. doi: 10.1038/ni0602-499

35. Gorden KK, Qiu XX, Binsfeld CC, Vasilakos JP, Alkan SS. Cutting edge: activation of murine TLR8 by a combination of imidazoquinoline immune response modifiers and polyT oligodeoxynucleotides. J Immunol. (2006) 177:6584-7. doi: 10.4049/jimmunol.177.10.6584

36. Martinez J, Huang X, Yang Y. Toll-like receptor 8-mediated activation of murine plasmacytoid dendritic cells by vaccinia viral DNA. Proc Natl Acad Sci USA. (2010) 107:6442-7. doi: 10.1073/pnas.0913291107

37. Oshiumi H, Matsumoto M, Funami K, Akazawa T, Seya T. TICAM-1, an adaptor molecule that participates in Toll-like receptor 3-mediated interferon-beta induction. Nat Immunol. (2003) 4:161-7. doi: 10.1038/ni886

38. Yamamoto M, Sato S, Hemmi H, Hoshino K, Kaisho T, Sanjo H, et al. Role of adaptor TRIF in the MyD88-independent toll-like receptor signaling pathway. Science. (2003) 301:640-3. doi: 10.1126/science.1087262

39. Jelinek I, Leonard JN, Price GE, Brown KN, Meyer-Manlapat A, Goldsmith PK, et al. TLR3-specific double-stranded RNA oligonucleotide adjuvants induce dendritic cell cross-presentation, CTL responses, and antiviral protection. J Immunol. (2011) 186:2422-9. doi: 10.4049/jimmunol.1002845

40. Azuma M, Ebihara T, Oshiumi H, Matsumoto M, Seya T. Cross-priming for antitumor CTL induced by soluble $\mathrm{Ag}+$ polyI:C depends on the TICAM-1 pathway in mouse CD11c $(+) / C D 8 a l p h a(+)$ dendritic cells. Oncoimmunology. (2012) 1:581-92. doi: 10.4161/onci.19893

41. Tatematsu M, Nishikawa F, Seya T, Matsumoto M. Toll-like receptor 3 recognizes incomplete stem structures in single-stranded viral RNA. Nat Commun. (2013) 4:1833. doi: 10.1038/ncomms2857

42. Matsumoto M, Funami K, Tanabe M, Oshiumi H, Shingai M, Seto Y, et al. Subcellular localization of Toll-like receptor 3 in human dendritic cells. $J$ Immunol. (2003) 171:3154-62. doi: 10.4049/jimmunol.171.6.3154

43. Akira S, Uematsu S, Takeuchi O. Pathogen recognition and innate immunity. Cell. (2006) 124:783-801. doi: 10.1016/j.cell.2006.02.015

44. Vaure C, Liu Y. A comparative review of toll-like receptor 4 expression and functionality in different animal species. Front Immunol. (2014) 5:316. doi: 10.3389/fimmu.2014.00316

45. Barchet W, Krug A, Cella M, Newby C, Fischer JA, Dzionek A, et al. Dendritic cells respond to influenza virus through TLR7- and PKR-independent pathways. Eur J Immunol. (2005) 35:236-42. doi: 10.1002/eji.200425583

46. Kumagai Y, Takeuchi O, Kato H, Kumar H, Matsui K, Morii E, et al. Alveolar macrophages are the primary interferon-alpha producer in pulmonary infection with RNA viruses. Immunity. (2007) 27:240-52. doi: $10.1016 /$ j.immuni.2007.07.013

47. $\mathrm{Wu} J$, Chen ZJ. Innate immune sensing and signaling of cytosolic nucleic acids. Аnnu Rev Immunol. (2014) 32:461-88. doi: 10.1146/annurev-immunol-032713-120156

48. Kumar H, Kawai T, Kato H, Sato S, Takahashi K, Coban C, et al. Essential role of IPS-1 in innate immune responses against RNA viruses. J Exp Med. (2006) 203:1795-803. doi: 10.1084/jem.20060792

49. Takeuchi O, Akira S. MDA5/RIG-I and virus recognition. Curr Opin Immunol. (2008) 20:17-22. doi: 10.1016/j.coi.2008.01.002

50. Reikine S, Nguyen JB, Modis Y. Pattern recognition and signaling mechanisms of RIG-I and MDA5. Front Immunol. (2014) 5:342. doi: $10.3389 /$ fimmu. 2014.00342

51. Stetson DB, Medzhitov R. Recognition of cytosolic DNA activates an IRF3-dependent innate immune response. Immunity. (2006) 24:93-103. doi: $10.1016 /$ j.immuni.2005.12.003

52. Holm CK, Paludan SR, Fitzgerald KA. DNA recognition in immunity and disease. Curr Opin Immunol. (2013) 25:13-8. doi: 10.1016/j.coi.2012.12.006

53. Sun L, Wu J, Du F, Chen X, Chen ZJ. Cyclic GMP-AMP synthase is a cytosolic DNA sensor that activates the type I interferon pathway. Science. (2013) 339:786-91. doi: 10.1126/science.1232458

54. Paludan SR, Bowie AG. Immune sensing of DNA. Immunity. (2013) 38:87080. doi: 10.1016/j.immuni.2013.05.004 
55. Takaoka A, Wang Z, Choi MK, Yanai H, Negishi H, Ban T, et al. DAI (DLM-1/ZBP1) is a cytosolic DNA sensor and an activator of innate immune response. Nature. (2007) 448:501-5. doi: 10.1038/nature06013

56. Unterholzner L, Keating SE, Baran M, Horan KA, Jensen SB, Sharma S, et al. IFI16 is an innate immune sensor for intracellular DNA. Nat Immunol. (2010) 11:997-1004. doi: 10.1038/ni.1932

57. Ablasser A, Goldeck M, Cavlar T, Deimling T, Witte G, Rohl I, et al. cGAS produces a 2'-5'-linked cyclic dinucleotide second messenger that activates STING. Nature. (2013) 498:380-4. doi: 10.1038/nature12306

58. Crowl JT, Gray EE, Pestal K, Volkman HE, Stetson DB. Intracellular nucleic acid detection in autoimmunity. Annu Rev Immunol. (2017) 35:313-36. doi: 10.1146/annurev-immunol-051116-052331

59. Scheu S, Dresing P, Locksley RM. Visualization of IFNbeta production by plasmacytoid versus conventional dendritic cells under specific stimulation conditions in vivo. Proc Natl Acad Sci USA. (2008) 105:20416-21. doi: $10.1073 /$ pnas.0808537105

60. Lienenklaus S, Cornitescu M, Zietara N, Lyszkiewicz M, Gekara N, Jablonska J, et al. Novel reporter mouse reveals constitutive and inflammatory expression of IFN-beta in vivo. J Immunol. (2009) 183:322936. doi: 10.4049/jimmunol.0804277

61. Allman D, Dalod M, Asselin-Paturel C, Delale T, Robbins SH, Trinchieri G, et al. Ikaros is required for plasmacytoid dendritic cell differentiation. Blood. (2006) 108:4025-34. doi: 10.1182/blood-2006-03-007757

62. Kirstetter P, Thomas M, Dierich A, Kastner P, Chan S. Ikaros is critical for B cell differentiation and function. Eur J Immunol. (2002) 32:720-30. doi: 10.1002/1521-4141(200203)32:3<720::AID-IMMU720>3.0.CO;2-P

63. Caton ML, Smith-Raska MR, Reizis B. Notch-RBP-J signaling controls the homeostasis of CD8- dendritic cells in the spleen. J Exp Med. (2007) 204:1653-64. doi: 10.1084/jem.20062648

64. Cisse B, Caton ML, Lehner M, Maeda T, Scheu S, Locksley R, et al. Transcription factor E2-2 is an essential and specific regulator of plasmacytoid dendritic cell development. Cell. (2008) 135:37-48. doi: 10.1016/j.cell.2008.09.016

65. Swiecki M, Gilfillan S, Vermi W, Wang Y, Colonna M. Plasmacytoid dendritic cell ablation impacts early interferon responses and antiviral $\mathrm{NK}$ and $\mathrm{CD} 8(+) \mathrm{T}$ cell accrual. Immunity. (2010) 33:955-66. doi: 10.1016/j.immuni.2010.11.020

66. Takagi H, Fukaya T, Eizumi K, Sato Y, Sato K, Shibazaki A, et al. Plasmacytoid dendritic cells are crucial for the initiation of inflammation and T cell immunity in vivo. Immunity. (2011) 35:958-71. doi: 10.1016/j.immuni.2011.10.014

67. Swiecki M, Wang Y, Riboldi E, Kim AH, Dzutsev A, Gilfillan S, et al. Cell depletion in mice that express diphtheria toxin receptor under the control of SiglecH encompasses more than plasmacytoid dendritic cells. J Immunol. (2014) 192:4409-16. doi: 10.4049/jimmunol.1303135

68. Puttur F, Arnold-Schrauf C, Lahl K, Solmaz G, Lindenberg M, Mayer CT, et al. Absence of Siglec-H in MCMV infection elevates interferon alpha production but does not enhance viral clearance. PLoS Pathog. (2013) 9:e1003648. doi: 10.1371/journal.ppat.1003648

69. Webster B, Werneke SW, Zafirova B, This S, Coleon S, Decembre E, et al. Plasmacytoid dendritic cells control dengue and Chikungunya virus infections via IRF7-regulated interferon responses. Elife. (2018) 7:e34273. doi: 10.7554/eLife. 34273

70. Jung S, Unutmaz D, Wong P, Sano G, De los Santos K, Sparwasser T, et al. In vivo depletion of $\mathrm{CD} 11 \mathrm{c}+$ dendritic cells abrogates priming of CD8+ T cells by exogenous cell-associated antigens. Immunity. (2002) 17:211-20. doi: 10.1016/S1074-7613(02)00365-5

71. Cailhier JF, Partolina M, Vuthoori S, Wu S, Ko K, Watson S, et al. Conditional macrophage ablation demonstrates that resident macrophages initiate acute peritoneal inflammation. J Immunol. (2005) 174:2336-42. doi: 10.4049/jimmunol.174.4.2336

72. Miyake Y, Asano K, Kaise H, Uemura M, Nakayama M, Tanaka M. Critical role of macrophages in the marginal zone in the suppression of immune responses to apoptotic cell-associated antigens. J Clin Invest. (2007) 117:2268-78. doi: 10.1172/JCI31990

73. Erlandsson L, Blumenthal R, Eloranta ML, Engel H, Alm G, Weiss S, et al. Interferon-beta is required for interferon-alpha production in mouse fibroblasts. Curr Biol. (1998) 8:223-6. doi: 10.1016/S0960-9822(98)70086-7
74. Deonarain R, Alcami A, Alexiou M, Dallman MJ, Gewert DR, Porter AC. Impaired antiviral response and alpha/beta interferon induction in mice lacking beta interferon. J Virol. (2000) 74:3404-9. doi: 10.1128/JVI.74.7.3404-3409.2000

75. Takaoka A, Mitani Y, Suemori H, Sato M, Yokochi T, Noguchi S, et al. Cross talk between interferon-gamma and -alpha/beta signaling components in caveolar membrane domains. Science. (2000) 288:2357-60. doi: 10.1126/science.288.5475.2357

76. Jung A, Kato H, Kumagai Y, Kumar H, Kawai T, Takeuchi O, et al. Lymphocytoid choriomeningitis virus activates plasmacytoid dendritic cells and induces a cytotoxic T-cell response via MyD88. J Virol. (2008) 82:196206. doi: 10.1128/JVI.01640-07

77. Frenz T, Graalmann L, Detje CN, Doring M, Grabski E, Scheu S, et al. Independent of plasmacytoid dendritic cell (pDC) infection, pDC triggered by virus-infected cells mount enhanced type I IFN responses of different composition as opposed to pDC stimulated with free virus. J Immunol. (2014) 193:2496-503. doi: 10.4049/jimmunol.1400215

78. Reizis B. Plasmacytoid dendritic cells: development, regulation, and function. Immunity. (2019) 50:37-50. doi: 10.1016/j.immuni.2018. 12.027

79. Swiecki M, Colonna M. Unraveling the functions of plasmacytoid dendritic cells during viral infections, autoimmunity, and tolerance. Immunol Rev. (2010) 234:142-62. doi: 10.1111/j.0105-2896.2009.00881.x

80. Krug A, French AR, Barchet W, Fischer JA, Dzionek A, Pingel JT, et al. TLR9dependent recognition of MCMV by IPC and DC generates coordinated cytokine responses that activate antiviral NK cell function. Immunity. (2004) 21:107-19. doi: 10.1016/j.immuni.2004.06.007

81. Dalod M, Salazar-Mather TP, Malmgaard L, Lewis C, Asselin-Paturel C, Briere $\mathrm{F}$, et al. Interferon alpha/beta and interleukin 12 responses to viral infections: pathways regulating dendritic cell cytokine expression in vivo. $J$ Exp Med. (2002) 195:517-28. doi: 10.1084/jem.20011672

82. Yoneyama H, Matsuno K, Toda E, Nishiwaki T, Matsuo N, Nakano A, et al. Plasmacytoid DCs help lymph node DCs to induce anti-HSV CTLs. J Exp Med. (2005) 202:425-35. doi: 10.1084/jem.20041961

83. Kuwajima S, Sato T, Ishida K, Tada H, Tezuka H, Ohteki T. Interleukin 15-dependent crosstalk between conventional and plasmacytoid dendritic cells is essential for CpG-induced immune activation. Nat Immunol. (2006) 7:740-6. doi: 10.1038/ni1348

84. Goubier A, Dubois B, Gheit H, Joubert G, Villard-Truc F, Asselin-Paturel C, et al. Plasmacytoid dendritic cells mediate oral tolerance. Immunity. (2008) 29:464-75. doi: 10.1016/j.immuni.2008.06.017

85. Shen H, Iwasaki A. A crucial role for plasmacytoid dendritic cells in antiviral protection by CpG ODN-based vaginal microbicide. J Clin Invest. (2006) 116:2237-43. doi: 10.1172/JCI28681

86. Asselin-Paturel C, Brizard G, Pin JJ, Briere F, Trinchieri G. Mouse strain differences in plasmacytoid dendritic cell frequency and function revealed by a novel monoclonal antibody. J Immunol. (2003) 171:6466-77. doi: 10.4049/jimmunol.171.12.6466

87. Loschko J, Schlitzer A, Dudziak D, Drexler I, Sandholzer N, Bourquin C, et al. Antigen delivery to plasmacytoid dendritic cells via BST2 induces protective T cell-mediated immunity. J Immunol. (2011) 186:6718-25. doi: 10.4049/jimmunol.1004029

88. Fleming TJ, Fleming ML, Malek TR. Selective expression of Ly-6G on myeloid lineage cells in mouse bone marrow. RB6-8C5 mAb to granulocytedifferentiation antigen (Gr-1) detects members of the Ly-6 family. $J$ Immunol. (1993) 151:2399-408.

89. Jutila MA, Kroese FG, Jutila KL, Stall AM, Fiering S, Herzenberg LA, et al. Ly-6C is a monocyte/macrophage and endothelial cell differentiation antigen regulated by interferon-gamma. Eur J Immunol. (1988) 18:1819-26. doi: 10.1002/eji.1830181125

90. Sato N, Yahata T, Santa K, Ohta A, Ohmi Y, Habu S, et al. Functional characterization of NK1.1 + Ly-6C+ cells. Immunol Lett. (1996) 54:5-9. doi: 10.1016/S0165-2478(96)02632-6

91. Takahama Y, Sharrow SO, Singer A. Expression of an unusual T cell receptor (TCR)-V beta repertoire by Ly-6C+ subpopulations of CD4+ and/or $\mathrm{CD} 8+$ thymocytes. Evidence for a developmental relationship between Ly$6 \mathrm{C}+$ thymocytes and CD4-CD8-TCR-alpha beta + thymocytes. J Immunol. (1991) 147:2883-91. 
92. Wrammert J, Kallberg E, Agace WW, Leanderson T. Ly6C expression differentiates plasma cells from other B cell subsets in mice. Eur J Immunol. (2002) 32:97-103. doi: 10.1002/1521-4141(200201)32:1<97::AID-IMMU97>3.0.CO;2-Y

93. Blasius AL, Giurisato E, Cella M, Schreiber RD, Shaw AS, Colonna M. Bone marrow stromal cell antigen 2 is a specific marker of type I IFN-producing cells in the naive mouse, but a promiscuous cell surface antigen following IFN stimulation. J Immunol. (2006) 177:3260-5. doi: 10.4049/jimmunol.177.5.3260

94. Lang PA, Recher M, Honke N, Scheu S, Borkens S, Gailus N, et al. Tissue macrophages suppress viral replication and prevent severe immunopathology in an interferon-I-dependent manner in mice. Hepatology. (2010) 52:25-32. doi: 10.1002/hep.23640

95. Louten J, van Rooijen N, Biron CA. Type 1 IFN deficiency in the absence of normal splenic architecture during lymphocytic choriomeningitis virus infection. J Immunol. (2006) 177:3266-72. doi: 10.4049/jimmunol.177.5.3266

96. Dumortier A, Jeannet R, Kirstetter P, Kleinmann E, Sellars M, dos Santos $\mathrm{NR}$, et al. Notch activation is an early and critical event during T-Cell leukemogenesis in Ikaros-deficient mice. Mol Cell Biol. (2006) 26:209-20. doi: 10.1128/MCB.26.1.209-220.2006

97. Dumortier A, Kirstetter P, Kastner P, Chan S. Ikaros regulates neutrophil differentiation. Blood. (2003) 101:2219-26. doi: 10.1182/blood-2002-05-1336

98. Zhuang Y, Cheng P, Weintraub H. B-lymphocyte development is regulated by the combined dosage of three basic helix-loop-helix genes, E2A, E2-2, and HEB. Mol Cell Biol. (1996) 16:2898-905. doi: 10.1128/MCB.16.6.2898

99. Bergqvist I, Eriksson M, Saarikettu J, Eriksson B, Corneliussen B, Grundstrom T, et al. The basic helix-loop-helix transcription factor E2-2 is involved in T lymphocyte development. Eur J Immunol. (2000) 30:2857-63. doi: 10.1002/1521-4141(200010)30:10<2857::AID-IMMU2857>3.0.CO;2-G

100. Cervantes-Barragan L, Lewis KL, Firner S, Thiel V, Hugues S, Reith $\mathrm{W}$, et al. Plasmacytoid dendritic cells control T-cell response to chronic viral infection. Proc Natl Acad Sci USA. (2012) 109:3012-7. doi: 10.1073/pnas.1117359109

101. Schlitzer A, Heiseke AF, Einwachter H, Reindl W, Schiemann M, Manta CP, et al. Tissue-specific differentiation of a circulating CCR9pDC-like common dendritic cell precursor. Blood. (2012) 119:6063-71. doi: 10.1182/blood-2012-03-418400

102. Loschko J, Heink S, Hackl D, Dudziak D, Reindl W, Korn T, et al. Antigen targeting to plasmacytoid dendritic cells via Siglec-H inhibits Th cell-dependent autoimmunity. J Immunol. (2011) 187:6346-56. doi: 10.4049/jimmunol.1102307

103. Feil R, Wagner J, Metzger D, Chambon P. Regulation of Cre recombinase activity by mutated estrogen receptor ligand-binding domains. Biochem Biophys Res Commun. (1997) 237:752-7. doi: 10.1006/bbrc.1997.7124

104. Barbalat R, Lau L, Locksley RM, Barton GM. Toll-like receptor 2 on inflammatory monocytes induces type I interferon in response to viral but not bacterial ligands. Nat Immunol. (2009) 10:1200-7. doi: 10.1038/ni.1792

105. Fejer G, Drechsel L, Liese J, Schleicher U, Ruzsics Z, Imelli N, et al. Key role of splenic myeloid DCs in the IFN-alphabeta response to adenoviruses in vivo. PLoS Pathog. (2008) 4:e1000208. doi: 10.1371/journal.ppat.1000208

106. McCartney SA, Vermi W, Lonardi S, Rossini C, Otero K, Calderon B, et al. RNA sensor-induced type I IFN prevents diabetes caused by a beta cell-tropic virus in mice. J Clin Invest. (2011) 121:1497-507. doi: 10.1172/JCI44005

107. Shaabani N, Duhan V, Khairnar V, Gassa A, Ferrer-Tur R, Haussinger D, et al. $\mathrm{CD169}(+)$ macrophages regulate PD-L1 expression via type I interferon and thereby prevent severe immunopathology after LCMV infection. Cell Death Dis. (2016) 7:e2446. doi: 10.1038/cddis.2016.350

108. Iannacone M, Moseman EA, Tonti E, Bosurgi L, Junt T, Henrickson $\mathrm{SE}$, et al. Subcapsular sinus macrophages prevent CNS invasion on peripheral infection with a neurotropic virus. Nature. (2010) 465:1079-83. doi: 10.1038/nature09118

109. Sapoznikov A, Fischer JA, Zaft T, Krauthgamer R, Dzionek A, Jung S. Organ-dependent in vivo priming of naive $\mathrm{CD} 4+$, but not $\mathrm{CD} 8+, \mathrm{T}$ cells by plasmacytoid dendritic cells. J Exp Med. (2007) 204:1923-33. doi: 10.1084/jem.20062373

110. Schneider K, Loewendorf A, De Trez C, Fulton J, Rhode A, Shumway H, et al. Lymphotoxin-mediated crosstalk between B cells and splenic stroma promotes the initial type I interferon response to cytomegalovirus. Cell Host Microbe. (2008) 3:67-76. doi: 10.1016/j.chom.2007.12.008

111. Bauer J, Dress RJ, Schulze A, Dresing P, Ali S, Deenen R, et al. Cutting edge: IFN-beta expression in the spleen is restricted to a subpopulation of plasmacytoid dendritic cells exhibiting a specific immune modulatory transcriptome signature. J Immunol. (2016) 196:4447-51. doi: 10.4049/jimmunol.1500383

112. Dalod M, Hamilton T, Salomon R, Salazar-Mather TP, Henry SC, Hamilton JD, et al. Dendritic cell responses to early murine cytomegalovirus infection: subset functional specialization and differential regulation by interferon alpha/beta. J Exp Med. (2003) 197:885-98. doi: 10.1084/jem.20021522

113. Delale T, Paquin A, Asselin-Paturel C, Dalod M, Brizard G, Bates EE, et al. MyD88-dependent and -independent murine cytomegalovirus sensing for IFN-alpha release and initiation of immune responses in vivo. J Immunol. (2005) 175:6723-32. doi: 10.4049/jimmunol.175.10.6723

114. Swiecki M, Wang Y, Gilfillan S, Colonna M. Plasmacytoid dendritic cells contribute to systemic but not local antiviral responses to HSV infections. PLoS Pathog. (2013) 9:e1003728. doi: 10.1371/journal.ppat.1003728

115. Stout-Delgado HW, Du W, Shirali AC, Booth CJ, Goldstein DR. Aging promotes neutrophil-induced mortality by augmenting IL-17 production during viral infection. Cell Host Microbe. (2009) 6:446-56 doi: 10.1016/j.chom.2009.09.011

116. Stout-Delgado HW, Yang X, Walker WE, Tesar BM, Goldstein DR. Aging impairs IFN regulatory factor 7 up-regulation in plasmacytoid dendritic cells during TLR9 activation. J Immunol. (2008) 181:6747-56. doi: 10.4049/jimmunol.181.10.6747

117. Lund JM, Linehan MM, Iijima $\mathrm{N}$, Iwasaki A. Cutting Edge: Plasmacytoid dendritic cells provide innate immune protection against mucosal viral infection in situ. J Immunol. (2006) 177:7510-4. doi: 10.4049/jimmunol.177.11.7510

118. Brewitz A, Eickhoff S, Dahling S, Quast T, Bedoui S, Kroczek RA, et al. CD8(+) T cells orchestrate pDC-XCR1(+) dendritic cell spatial and functional cooperativity to optimize priming. Immunity. (2017) 46:205-19. doi: 10.1016/j.immuni.2017.01.003

119. Xu RH, Wong EB, Rubio D, Roscoe F, Ma X, Nair S, et al. Sequential activation of two pathogen-sensing pathways required for type I interferon expression and resistance to an acute DNA virus infection. Immunity. (2015) 43:1148-59. doi: 10.1016/j.immuni.2015.11.015

120. Wolf AI, Buehler D, Hensley SE, Cavanagh LL, Wherry EJ, Kastner P, et al. Plasmacytoid dendritic cells are dispensable during primary influenza virus infection. J Immunol. (2009) 182:871-9. doi: 10.4049/jimmunol.182.2.871

121. Kochs G, Anzaghe M, Kronhart S, Wagner V, Gogesch P, Scheu S, et al. In vivo conditions enable IFNAR-independent type I interferon production by peritoneal CD11b+ cells upon thogoto virus infection. J Virol. (2016) 90:9330-7. doi: 10.1128/JVI.00744-16

122. Kallfass C, Ackerman A, Lienenklaus S, Weiss S, Heimrich B, Staeheli P. Visualizing production of beta interferon by astrocytes and microglia in brain of La Crosse virus-infected mice. J Virol. (2012) 86:11223-30. doi: 10.1128/JVI.01093-12

123. Delhaye S, Paul S, Blakqori G, Minet M, Weber F, Staeheli P, et al. Neurons produce type I interferon during viral encephalitis. Proc Natl Acad Sci USA. (2006) 103:7835-40. doi: 10.1073/pnas.0602460103

124. Cervantes-Barragan L, Zust R, Weber F, Spiegel M, Lang KS, Akira $\mathrm{S}$, et al. Control of coronavirus infection through plasmacytoid dendritic-cell-derived type I interferon. Blood. (2007) 109:1131-7. doi: 10.1182/blood-2006-05-023770

125. Wang Y, Swiecki M, Cella M, Alber G, Schreiber RD, Gilfillan S, et al. Timing and magnitude of type I interferon responses by distinct sensors impact CD8 T cell exhaustion and chronic viral infection. Cell Host Microbe. (2012) 11:631-42. doi: 10.1016/j.chom.2012.05.003

126. Smit JJ, Rudd BD, Lukacs NW. Plasmacytoid dendritic cells inhibit pulmonary immunopathology and promote clearance of respiratory syncytial virus. J Exp Med. (2006) 203:1153-9. doi: 10.1084/jem.20052359

127. Swiecki M, Colonna M. Type I interferons: diversity of sources, production pathways and effects on immune responses. Curr Opin Virol. (2011) 1:46375. doi: 10.1016/j.coviro.2011.10.026

128. Alcami A, Koszinowski UH. Viral mechanisms of immune evasion. Mol Med Today. (2000) 6:365-72. doi: 10.1016/S1357-4310(00)01775-5 
129. Zucchini N, Bessou G, Traub S, Robbins SH, Uematsu S, Akira S, et al. Cutting edge: Overlapping functions of TLR7 and TLR9 for innate defense against a herpesvirus infection. J Immunol. (2008) 180:5799-803. doi: 10.4049/jimmunol.180.9.5799

130. Doring M, Lessin I, Frenz T, Spanier J, Kessler A, Tegtmeyer P, et al. M27 expressed by cytomegalovirus counteracts effective type I interferon induction of myeloid cells but not of plasmacytoid dendritic cells. J Virol. (2014) 88:13638-50. doi: 10.1128/JVI.00216-14

131. Szomolanyi-Tsuda E, Liang X, Welsh RM, Kurt-Jones EA, Finberg RW. Role for TLR2 in NK cell-mediated control of murine cytomegalovirus in vivo. $J$ Virol. (2006) 80:4286-91. doi: 10.1128/JVI.80.9.4286-4291.2006

132. Tabeta K, Georgel P, Janssen E, Du X, Hoebe K, Crozat K, et al. Tolllike receptors 9 and 3 as essential components of innate immune defense against mouse cytomegalovirus infection. Proc Natl Acad Sci USA. (2004) 101:3516-21. doi: 10.1073/pnas.0400525101

133. Eloranta ML, Alm GV. Splenic marginal metallophilic macrophages and marginal zone macrophages are the major interferon-alpha/beta producers in mice upon intravenous challenge with herpes simplex virus. Scand $J$ Immunol. (1999) 49:391-4. doi: 10.1046/j.1365-3083.1999.00514.x

134. ME JW, Adair K, Brierley L. RNA viruses: a case study of the biology of emerging infectious diseases. Microbiol Spectr. (2013) 1:1-11. doi: 10.1128/microbiolspec.OH-0001-2012

135. Shi M, Lin XD, Chen X, Tian JH, Chen LJ, Li K, et al. The evolutionary history of vertebrate RNA viruses. Nature. (2018) 556:197-202. doi: 10.1038/s41586-018-0012-7

136. Hornung V, Schlender J, Guenthner-Biller M, Rothenfusser S, Endres S, Conzelmann KK, et al. Replication-dependent potent IFN-alpha induction in human plasmacytoid dendritic cells by a single-stranded RNA virus. $J$ Immunol. (2004) 173:5935-43. doi: 10.4049/jimmunol.173.10.5935

137. Lee HK, Lund JM, Ramanathan B, Mizushima N, Iwasaki A. Autophagydependent viral recognition by plasmacytoid dendritic cells. Science. (2007) 315:1398-401. doi: 10.1126/science. 1136880

138. Honke N, Shaabani N, Cadeddu G, Sorg UR, Zhang DE, Trilling M, et al. Enforced viral replication activates adaptive immunity and is essential for the control of a cytopathic virus. Nat Immunol. (2011) 13:51-7. doi: $10.1038 /$ ni. 2169

139. Pfefferkorn C, Kallfass C, Lienenklaus S, Spanier J, Kalinke U, Rieder M, et al. Abortively infected astrocytes appear to represent the main source of interferon beta in the virus-infected brain. J Virol. (2016) 90:2031-8. doi: 10.1128/JVI.02979-15

140. Davidson S, Kaiko G, Loh Z, Lalwani A, Zhang V, Spann K, et al. Plasmacytoid dendritic cells promote host defense against acute pneumovirus infection via the TLR7-MyD88-dependent signaling pathway. J Immunol. (2011) 186:5938-48. doi: 10.4049/jimmunol.1002635

141. O’Brien M, Manches O, Bhardwaj N. Plasmacytoid dendritic cells in HIV infection. Adv Exp Med Biol. (2013) 762:71-107. doi: 10.1007/978-1-4614-4433-6_3

142. Feldman S, Stein D, Amrute S, Denny T, Garcia Z, Kloser P, et al. Decreased interferon-alpha production in HIV-infected patients correlates with numerical and functional deficiencies in circulating type 2 dendritic cell precursors. Clin Immunol. (2001) 101:201-10. doi: 10.1006/clim.2001.5111

143. Herbeuval JP, Shearer GM. HIV-1 immunopathogenesis: how good interferon turns bad. Clin Immunol. (2007) 123:121-8. doi: 10.1016/j.clim.2006.09.016

144. Hosmalin A, Lebon P. Type I interferon production in HIV-infected patients. J Leukoc Biol. (2006) 80:984-93. doi: 10.1189/jlb.0306154

145. Kovarik P, Castiglia V, Ivin M, Ebner F. Type I interferons in bacterial infections: a Balancing Act. Front Immunol. (2016) 7:652. doi: 10.3389/fimmu.2016.00652

146. O'Garra A, Redford PS, McNab FW, Bloom CI, Wilkinson RJ, Berry MP. The immune response in tuberculosis. Annu Rev Immunol. (2013) 31:475-527. doi: 10.1146/annurev-immunol-032712-095939

147. Kearney SJ, Delgado C, Eshleman EM, Hill KK, O’Connor BP, Lenz LL. Type I IFNs downregulate myeloid cell IFN-gamma receptor by inducing recruitment of an early growth response 3/NGFI-A binding protein 1 complex that silences ifngr1 transcription. J Immunol. (2013) 191:3384-92. doi: 10.4049/jimmunol.1203510
148. Rayamajhi M, Humann J, Penheiter K, Andreasen K, Lenz LL. Induction of IFN-alphabeta enables Listeria monocytogenes to suppress macrophage activation by IFN-gamma. J Exp Med. (2010) 207:327-37. doi: 10.1084/jem.20091746

149. Stanley SA, Johndrow JE, Manzanillo P, Cox JS. The Type I IFN response to infection with Mycobacterium tuberculosis requires ESX-1-mediated secretion and contributes to pathogenesis. J Immunol. (2007) 178:3143-52. doi: 10.4049/jimmunol.178.5.3143

150. Mayer-Barber KD, Andrade BB, Barber DL, Hieny S, Feng CG, Caspar P, et al. Innate and adaptive interferons suppress IL-1alpha and IL-1beta production by distinct pulmonary myeloid subsets during Mycobacterium tuberculosis infection. Immunity. (2011) 35:1023-34. doi: 10.1016/j.immuni.2011.12.002

151. Giacomini E, Iona E, Ferroni L, Miettinen M, Fattorini L, Orefici $\mathrm{G}$, et al. Infection of human macrophages and dendritic cells with Mycobacterium tuberculosis induces a differential cytokine gene expression that modulates T cell response. J Immunol. (2001) 166:7033-41. doi: 10.4049/jimmunol.166.12.7033

152. Remoli ME, Giacomini E, Lutfalla G, Dondi E, Orefici G, Battistini A, et al. Selective expression of type I IFN genes in human dendritic cells infected with Mycobacterium tuberculosis. J Immunol. (2002) 169:366-74. doi: 10.4049/jimmunol.169.1.366

153. Teles RM, Graeber TG, Krutzik SR, Montoya D, Schenk M, Lee DJ, et al. Type I interferon suppresses type II interferon-triggered human anti-mycobacterial responses. Science. (2013) 339:1448-53. doi: $10.1126 /$ science. 1233665

154. Auerbuch V, Brockstedt DG, Meyer-Morse N, O’Riordan M, Portnoy DA. Mice lacking the type I interferon receptor are resistant to Listeria monocytogenes. J Exp Med. (2004) 200:527-33. doi: 10.1084/jem.20040976

155. Carrero JA, Calderon B, Unanue ER. Listeriolysin O from Listeria monocytogenes is a lymphocyte apoptogenic molecule. J Immunol. (2004) 172:4866-74. doi: 10.4049/jimmunol.172.8.4866

156. O'Connell RM, Saha SK, Vaidya SA, Bruhn KW, Miranda GA, Zarnegar B, et al. Type I interferon production enhances susceptibility to Listeria monocytogenes infection. J Exp Med. (2004) 200:437-45. doi: 10.1084/jem.20040712

157. Kernbauer E, Maier V, Rauch I, Muller M, Decker T. Route of infection determines the impact of type I interferons on innate immunity to listeria monocytogenes. PLoS ONE. (2013) 8:e65007. doi: 10.1371/journal.pone.0065007

158. Pitts MG, Myers-Morales T, D’Orazio SE. Type I IFN does not promote susceptibility to foodborne listeria monocytogenes. J Immunol. (2016) 196:3109-16. doi: 10.4049/jimmunol.1502192

159. Stockinger S, Kastner R, Kernbauer E, Pilz A, Westermayer S, Reutterer $\mathrm{B}$, et al. Characterization of the interferon-producing cell in mice infected with Listeria monocytogenes. PLoS Pathog. (2009) 5:e1000355. doi: 10.1371/journal.ppat.1000355

160. Dresing P, Borkens S, Kocur M, Kropp S, Scheu S. A fluorescence reporter model defines "Tip-DCs" as the cellular source of interferon beta in murine listeriosis. PLoS ONE. (2010) 5:e15567. doi: 10.1371/journal.pone.0015567

161. Solodova E, Jablonska J, Weiss S, Lienenklaus S. Production of IFN-beta during Listeria monocytogenes infection is restricted to monocyte/macrophage lineage. PLoS ONE. (2011) 6:e18543. doi: 10.1371/journal.pone.0018543

162. Serbina NV, Salazar-Mather TP, Biron CA, Kuziel WA, Pamer EG. TNF/iNOS-producing dendritic cells mediate innate immune defense against bacterial infection. Immunity. (2003) 19:59-70. doi: 10.1016/S1074-7613(03)00171-7

163. Bao Y, Han Y, Chen Z, Xu S, Cao X. IFN-alpha-producing PDCA-1+ Siglec$\mathrm{H}$ - B cells mediate innate immune defense by activating NK cells. Eur J Immunol. (2011) 41:657-68. doi: 10.1002/eji.201040840

164. O'Riordan M, Yi CH, Gonzales R, Lee KD, Portnoy DA. Innate recognition of bacteria by a macrophage cytosolic surveillance pathway. Proc Natl Acad Sci USA. (2002) 99:13861-6. doi: 10.1073/pnas.202476699

165. Stockinger S, Materna T, Stoiber D, Bayr L, Steinborn R, Kolbe T, et al. Production of type I IFN sensitizes macrophages to cell death induced by Listeria monocytogenes. J Immunol. (2002) 169:6522-9. doi: 10.4049/jimmunol.169.11.6522 
166. Serbina NV, Shi C, Pamer EG. Monocyte-mediated immune defense against murine Listeria monocytogenes infection. Adv Immunol. (2012) 113:119-34. doi: 10.1016/B978-0-12-394590-7.00003-8

167. Mancuso G, Midiri A, Biondo C, Beninati C, Zummo S, Galbo R, et al. Type I IFN signaling is crucial for host resistance against different species of pathogenic bacteria. J Immunol. (2007) 178:3126-33. doi: 10.4049/jimmunol.178.5.3126

168. Mancuso G, Gambuzza M, Midiri A, Biondo C, Papasergi S, Akira S, et al. Bacterial recognition by TLR7 in the lysosomes of conventional dendritic cells. Nat Immunol. (2009) 10:587-94. doi: 10.1038/ni.1733

169. Weighardt H, Kaiser-Moore S, Schlautkotter S, Rossmann-Bloeck T, Schleicher U, Bogdan C, et al. Type I IFN modulates host defense and late hyperinflammation in septic peritonitis. J Immunol. (2006) 177:5623-30. doi: 10.4049/jimmunol.177.8.5623

170. Ramirez-Ortiz ZG, Lee CK, Wang JP, Boon L, Specht CA, Levitz SM. A nonredundant role for plasmacytoid dendritic cells in host defense against the human fungal pathogen Aspergillus fumigatus. Cell Host Microbe. (2011) 9:415-24. doi: 10.1016/j.chom.2011.04.007

171. Beiting DP. Protozoan parasites and type I interferons: a cold case reopened. Trends Parasitol. (2014) 30:491-8. doi: 10.1016/j.pt.2014.07.007

172. Silva-Barrios S, Stager S. Protozoan parasites and type I IFNs. Front Immunol. (2017) 8:14. doi: 10.3389/fimmu.2017.00014

173. deWalick S, Amante FH, McSweeney KA, Randall LM, Stanley AC, Haque A, et al. Cutting edge: conventional dendritic cells are the critical APC required for the induction of experimental cerebral malaria. J Immunol. (2007) 178:6033-7. doi: 10.4049/jimmunol.178.10.6033

174. Haque A, Best SE, Montes de Oca M, James KR, Ammerdorffer A, Edwards CL, et al. Type I IFN signaling in CD8- DCs impairs Th1-dependent malaria immunity. J Clin Invest. (2014) 124:2483-96. doi: 10.1172/JCI70698

175. Voisine C, Mastelic B, Sponaas AM, Langhorne J. Classical CD11c+ dendritic cells, not plasmacytoid dendritic cells, induce $\mathrm{T}$ cell responses to Plasmodium chabaudi malaria. Int J Parasitol. (2010) 40:711-9. doi: 10.1016/j.ijpara.2009.11.005

176. Kim CC, Nelson CS, Wilson EB, Hou B, DeFranco AL, DeRisi JL. Splenic red pulp macrophages produce type I interferons as early sentinels of malaria infection but are dispensable for control. PLoS ONE. (2012) 7:e48126. doi: 10.1371/journal.pone.0048126

177. Spaulding E, Fooksman D, Moore JM, Saidi A, Feintuch CM, Reizis B, et al. STING-licensed macrophages prime type I IFN production by plasmacytoid dendritic cells in the bone marrow during severe Plasmodium yoelii malaria. PLoS Pathog. (2016) 12:e1005975. doi: 10.1371/journal.ppat.1005975

178. Yu X, Cai B, Wang M, Tan P, Ding X, Wu J, et al. Cross-regulation of two type I interferon signaling pathways in plasmacytoid dendritic cells controls anti-malaria immunity and host mortality. Immunity. (2016) 45:1093-107. doi: 10.1016/j.immuni.2016.10.001

179. Silva-Barrios S, Smans M, Duerr CU, Qureshi ST, Fritz JH, Descoteaux A, et al. Innate immune B cell activation by Leishmania donovani exacerbates disease and mediates hypergammaglobulinemia. Cell Rep. (2016) 15:242737. doi: 10.1016/j.celrep.2016.05.028

180. Minns LA, Menard LC, Foureau DM, Darche S, Ronet C, Mielcarz DW, et al. TLR9 is required for the gut-associated lymphoid tissue response following oral infection of Toxoplasma gondii. J Immunol. (2006) 176:758997. doi: 10.4049/jimmunol.176.12.7589

181. Han SJ, Melichar HJ, Coombes JL, Chan SW, Koshy AA, Boothroyd JC, et al. Internalization and TLR-dependent type I interferon production by monocytes in response to Toxoplasma gondii. Immunol Cell Biol. (2014) 92:872-81. doi: 10.1038/icb.2014.70

182. Sebina I, Haque A. Effects of type I interferons in malaria. Immunology. (2018) 155:176-85. doi: 10.1111/imm.12971

183. Pichyangkul S, Yongvanitchit K, Kum-arb U, Hemmi H, Akira S, Krieg AM, et al. Malaria blood stage parasites activate human plasmacytoid dendritic cells and murine dendritic cells through a Toll-like receptor 9-dependent pathway. J Immunol. (2004) 172:4926-33. doi: 10.4049/jimmunol.172.8.4926

184. Liehl P, Zuzarte-Luis V, Chan J, Zillinger T, Baptista F, Carapau D, et al. Hostcell sensors for Plasmodium activate innate immunity against liver-stage infection. Nat Med. (2014) 20:47-53. doi: 10.1038/nm.3424

185. Wilson EB, Yamada DH, Elsaesser H, Herskovitz J, Deng J, Cheng $\mathrm{G}$, et al. Blockade of chronic type I interferon signaling to control persistent LCMV infection. Science. (2013) 340:202-7. doi: 10.1126/science. 1235208

186. Beignon AS, McKenna K, Skoberne M, Manches O, DaSilva I, Kavanagh DG, et al. Endocytosis of HIV-1 activates plasmacytoid dendritic cells via Toll-like receptor-viral RNA interactions. J Clin Invest. (2005) 115:3265-75. doi: 10.1172/JCI26032

187. Schleicher U, Liese J, Justies N, Mischke T, Haeberlein S, Sebald H, et al. Type I interferon signaling is required for CpG-Oligodesoxynucleotide-induced control of Leishmania major, but not for spontaneous cure of subcutaneous primary or secondary L. major infection. Front Immunol. (2018) 9:79. doi: 10.3389/fimmu.2018.00079

188. Diefenbach A, Schindler H, Donhauser N, Lorenz E, Laskay T, MacMicking J, et al. Type 1 interferon (IFNalpha/beta) and type 2 nitric oxide synthase regulate the innate immune response to a protozoan parasite. Immunity. (1998) 8:77-87. doi: 10.1016/S1074-7613(00)80460-4

189. Bogdan C, Mattner J, Schleicher U. The role of type I interferons in non-viral infections. Immunol Rev. (2004) 202:33-48. doi: 10.1111/j.0105-2896.2004.00207.x

190. Vivarini Ade C, Pereira Rde M, Teixeira KL, Calegari-Silva TC, Bellio M, Laurenti MD, et al. Human cutaneous leishmaniasis: interferon-dependent expression of double-stranded RNA-dependent protein kinase (PKR) via TLR2. FASEB J. (2011) 25:4162-73. doi: 10.1096/fj.11-185165

191. Schleicher U, Liese J, Knippertz I, Kurzmann C, Hesse A, Heit A, et al. NK cell activation in visceral leishmaniasis requires TLR9, myeloid DCs, and IL12, but is independent of plasmacytoid DCs. J Exp Med. (2007) 204:893-906. doi: 10.1084/jem.20061293

192. Pepper M, Dzierszinski F, Wilson E, Tait E, Fang Q, Yarovinsky F, et al. Plasmacytoid dendritic cells are activated by Toxoplasma gondii to present antigen and produce cytokines. J Immunol. (2008) 180:6229-36. doi: 10.4049/jimmunol.180.9.6229

193. Koblansky AA, Jankovic D, Oh H, Hieny S, Sungnak W, Mathur $\mathrm{R}$, et al. Recognition of profilin by Toll-like receptor 12 is critical for host resistance to Toxoplasma gondii. Immunity. (2013) 38:119-30. doi: 10.1016/j.immuni.2012.09.016

194. Pierog PL, Zhao Y, Singh S, Dai J, Yap GS, Fitzgerald-Bocarsly P. Toxoplasma gondii inactivates human plasmacytoid dendritic cells by functional Mimicry of IL-10. J Immunol. (2018) 200:186-95. doi: 10.4049/jimmunol.1701045

195. Leng J, Butcher BA, Denkers EY. Dysregulation of macrophage signal transduction by Toxoplasma gondii: past progress and recent advances. Parasite Immunol. (2009) 31:717-28. doi: 10.1111/j.1365-3024.2009. 01122.x

196. Melo MB, Nguyen QP, Cordeiro C, Hassan MA, Yang N, McKell R, et al. Transcriptional analysis of murine macrophages infected with different Toxoplasma strains identifies novel regulation of host signaling pathways. PLoS Pathog. (2013) 9:e1003779.

197. Beiting DP, Peixoto L, Akopyants NS, Beverley SM, Wherry EJ, Christian $\mathrm{DA}$, et al. Differential induction of TLR3-dependent innate immune signaling by closely related parasite species. PLOS ONE. (2014) 9:e88398. doi: 10.1371/journal.pone.0088398

198. Swiecki M, Wang Y, Vermi W, Gilfillan S, Schreiber RD, Colonna M. Type I interferon negatively controls plasmacytoid dendritic cell numbers in vivo. J Exp Med. (2011) 208:2367-74. doi: 10.1084/jem.20110654

199. Tomasello E, Pollet E, Vu Manh TP, Uze G, Dalod M. Harnessing mechanistic knowledge on beneficial versus deleterious IFN-I effects to design innovative immunotherapies targeting cytokine activity to specific cell types. Front Immunol. (2014) 5:526. doi: 10.3389/fimmu.2014.00526

Conflict of Interest Statement: The authors declare that the research was conducted in the absence of any commercial or financial relationships that could be construed as a potential conflict of interest.

Copyright (c) 2019 Ali, Mann-Nüttel, Schulze, Richter, Alferink and Scheu. This is an open-access article distributed under the terms of the Creative Commons Attribution License (CC BY). The use, distribution or reproduction in other forums is permitted, provided the original author(s) and the copyright owner(s) are credited and that the original publication in this journal is cited, in accordance with accepted academic practice. No use, distribution or reproduction is permitted which does not comply with these terms. 